Review

\title{
At a Crossroads to Cancer: How p53-Induced Cell Fate Decisions Secure Genome Integrity
}

\author{
Dario Rizzotto $^{1}\left(\mathbb{D}\right.$, Lukas Englmaier ${ }^{1,2}$ and Andreas Villunger $1,2,3, *$ (D) \\ 1 CeMM Research Center for Molecular Medicine of the Austrian Academy of Sciences, 1090 Vienna, Austria; \\ DRizzotto@cemm.oeaw.ac.at (D.R.); Lukas.Englmaier@rud.lbg.ac.at (L.E.) \\ 2 Ludwig Boltzmann Institute for Rare and Undiagnosed Diseases (LBI-RUD), 1090 Vienna, Austria \\ 3 Institute for Developmental Immunology, Biocenter, Medical University of Innsbruck, 6020 Innsbruck, Austria \\ * Correspondence: andreas.villunger@i-med.ac.at
}

check for updates

Citation: Rizzotto, D.; Englmaier, L.; Villunger, A. At a Crossroads to Cancer: How p53-Induced Cell Fate Decisions Secure Genome Integrity. Int. J. Mol. Sci. 2021, 22, 10883.

https://doi.org/10.3390/ijms221910883

Academic Editors: Andreas Prokesch and Jelena Krstic

Received: 2 September 2021

Accepted: 1 October 2021

Published: 8 October 2021

Publisher's Note: MDPI stays neutral with regard to jurisdictional claims in published maps and institutional affiliations.

Copyright: (c) 2021 by the authors. Licensee MDPI, Basel, Switzerland. This article is an open access article distributed under the terms and conditions of the Creative Commons Attribution (CC BY) license (https:// creativecommons.org/licenses/by/ $4.0 /)$

\begin{abstract}
P53 is known as the most critical tumor suppressor and is often referred to as the guardian of our genome. More than 40 years after its discovery, we are still struggling to understand all molecular details on how this transcription factor prevents oncogenesis or how to leverage current knowledge about its function to improve cancer treatment. Multiple cues, including DNA-damage or mitotic errors, can lead to the stabilization and nuclear translocation of p53, initiating the expression of multiple target genes. These transcriptional programs may be cell-type- and stimulus-specific, as is their outcome that ultimately imposes a barrier to cellular transformation. Cell cycle arrest and cell death are two well-studied consequences of p53 activation, but, while being considered critical, they do not fully explain the consequences of p53 loss-of-function phenotypes in cancer. Here, we discuss how mitotic errors alert the $\mathrm{p} 53$ network and give an overview of multiple ways that p53 can trigger cell death. We argue that a comparative analysis of different types of p53 responses, elicited by different triggers in a time-resolved manner in well-defined model systems, is critical to understand the cell-type-specific cell fate induced by p53 upon its activation in order to resolve the remaining mystery of its tumor-suppressive function.
\end{abstract}

Keywords: p53; cell cycle; DREAM-complex; cell death; PIDDosome; CIN; aneuploidy

\section{Introduction}

Despite decades of research, cancer remains one of the leading causes of death worldwide, and particularly in developed countries its incidence is still on the rise. Cancer usually arises upon long latency in response to a series of genetic alterations, triggered by exogenous (environmental exposition) and endogenous causes (genetic predisposition) that are additionally modulated by pathobionts, such as bacteria or viruses, making it very difficult to predict the time of its occurrence, its clinical progression, and treatability [1-6].

However, neoplastic cells originating from different tissues often display similar molecular features, for example, the overexpression or mutation of proto-oncogenes, such as MYC or RAS, or the inactivation of tumor-suppressor genes. Perhaps the most common gene of this kind that is inactivated or lost in human cancers is TP53 (herein, p53). Nearly all the events currently known to compromise the genomic integrity of the cell (thus being potential drivers of transformation) can lead to p53 activation. This requires protein stabilization, accumulation, and translocation into the nucleus, where p53 can elicit its function as a sequence-specific transcription factor [7]. Moreover, direct cell-death-promoting effector functions have also been proposed and will be discussed later.

Stunningly, despite extensive research into its biology and more than 100,000 papers cited in PubMed, we still fall short in understanding how p53 actually prevents cancer and how we could exploit current knowledge therapeutically.

The two best-studied cellular responses controlled by p53 are cell cycle arrest and the induction of apoptosis, both of which aim to preserve genomic integrity for tissue 
homeostasis [8-11]. Indeed, active p53 promotes the transcription of $C D K N 1 A$, the gene encoding the potent cyclin-dependent kinase inhibitor p21 [12], and several genes encoding proteins involved in regulating mitochondrial and death-receptor-driven apoptosis $[8,13]$. Yet, cell cycle arrest and apoptosis are only two of the many tumor-suppressive functions controlled by p53 [14-16]. Consistently, impairing the ability of p53 to activate CDKN1A and its apoptotic effectors does not impair its ability to suppress cancer $[17,18]$. This suggests additional mechanisms at play, likely those reducing the mutational burden and the maintenance of genome integrity $[8,19,20]$. Yet, alteration or loss of either of these effector's arms can contribute to tumorigenesis as well as drug resistance phenotypes, as documented in multiple studies [21-26].

The importance of p53 in maintaining genome integrity becomes clear when looking at malignant cells in which the transcription factor is lost, mutated, or inactivated. Indeed, a common feature of these cells is genomic instability, which is reflected by the increased accumulation of alterations at different levels, from mutations of the genetic sequence to alterations in chromosomes' structure and number [27]. Alterations noted at the level of the chromosomes are summarized as chromosomal instability (CIN) or, upon fixation, aneuploidy. CIN arises from errors during the mitotic process, caused by defects in checkpoints controlling mitotic entry, regulated by checkpoint kinase 1 (CHK1) [28], or mitotic exit, controlled by the E3-ligase, APC/C, and its activator CDC20, as well as the spindle assembly checkpoint (SAC), ensuring the integrity of kinetochore-microtubule attachments in prometaphase $[29,30]$. Moreover, errors in centrosome biogenesis and number can also foster CIN, e.g., during multipolar mitoses [31-34]. Impairment of any of these control mechanisms can cause the missegregation of chromosomes into daughter cells, resulting in aneuploidy, an ultimately fixed abnormal number of chromosomes deviating from the physiological karyotype [35]. CIN and aneuploidy are interconnected [27], and they contribute to increasing intra-cancer heterogeneity, which in turn can confer a selective advantage, for example, in the development of resistance to conventional or targeted therapies [36,37]. Nonetheless, aneuploid cells often show initially decreased fitness, proteostasis, and proliferation defects, together with an increased susceptibility towards cell death [38-40]. This suggests that aneuploidy might be only beneficial in certain contexts after sampling the right set of chromosomes, allowing survival and outgrowth of cells with complex karyotypes. Hence, aneuploidy is often considered a rather late event in tumorigenesis, driving cancer evolution, but may not necessarily be responsible for tumor initiation [31,36]. Yet, this is an ongoing debate [38].

As stated before, p53 inactivation is a common feature of many cancers. The most prominent way of inactivating p53 is through mutations, often occurring in the DNA binding domain of the transcription factor [41-43]. Germline mutations in the TP53 gene are associated with the Li-Fraumeni syndrome, whose patients are prone to develop multiorgan cancers, often in the childhood [44,45]. Nevertheless, inherited single nucleotide polymorphisms (SNPs) have been identified in the TP53 loci and have been reviewed and discussed in detail elsewhere [46,47]. The impact of SNPs on tumor susceptibility is not easy to assess mechanistically (using both in vitro and animal models). To exemplify this complexity, one of the most common polymorphisms affecting p53 occurs on codon 72, which encodes for either a proline (P72) or an arginine (R72). The R72 variant has been shown to correlate with the establishment of a successful apoptotic program upon p53 activation in cell models [48], also due to a better induction of CDKN1A and BAX [49]. Nevertheless, in a breast cancer mouse model, the P72 variant seems to be protective against carcinogenesis compared to the R72 variant [50]. Cohort studies in cancer patients and meta-analyses did not lead to univocal results, such as, for example, the R72 variant, which seems to favor HPV-associated cervical carcinoma in vitro [51] but does not lead to an increased risk of cervical cancer in patients [52]. Yet, this variant has been identified as a risk factor for breast cancer [53,54]. Further analyses aimed at assessing the impact of the different SNPs are needed to clarify their contribution to tumorigenesis. 
Interestingly, genetic variants affecting genes of the p53 pathway (both upstream activators of the transcription factor and the downstream targets) influence cancer susceptibility [55].

\section{How p53 Puts the Break on CIN and Aneuploidy}

CIN and aneuploidy are frequently preceded by defects in cytokinesis, referring to the process allowing the mother cell that has duplicated its genome to physically separate into the two daughter cells at the end of mitosis [56,57]. In this situation, the cell undergoes whole-genome duplication, most commonly leading to tetraploidization [57]. It is believed that tetraploidization is an early event occurring in many cancers [58], which can foster CIN and aneuploidy in subsequent rounds of cell division. Moreover, tetraploid cells are more tolerant to chromosome loss compared to their diploid counterparts and consequently are more "fit" to undergo cancer-promoting alterations [36]. Another consequence of cytokinesis failure is the acquisition of extra centrosomes [59], which are microtubule-organizing centers (MTOCs) responsible for generating the mitotic spindle during prophase [60]. In mitosis, the presence of extra centrosomes can lead to multipolar cell division, which is highly error-prone [9,59] due to frequent merotelic kinetochore-microtubule attachments [59]. Not surprisingly, extra centrosomes are frequently seen in cancer lesions and are also discussed to increase the invasiveness of tumor cells [61,62].

Remarkably, p53 signaling can halt cells harboring an altered centrosome number as well as cells experiencing problems during mitosis that primes them for chromosome mis-segregation [63]. As an example, extended mitotic duration due to persistent activation of the SAC, which senses unattached kinetochores not bound to the mitotic spindle, can trigger a p53-dependent cell-cycle arrest [64-66] (Figure 1). This mechanism relies on 53BP1 and USP28 that stabilize p53 by removing ubiquitination performed by MDM2, the main E3-ligase controlling p53 protein levels. This allows its accumulation and the induction of p21, arresting the cell in the next G1 [64-66]. Of note, the quality of this type of p53 response is expected to differ from the one induced upon DNA damage, where 53BP1 is known for rapidly accumulating on chromatin at the sites of double-strand breaks and providing a scaffold for factors involved in DNA repair [67]. Under these conditions, p53 stabilization primarily depends on post-translational modifications (PTMs) mediated by kinases of the DNA damage response (DDR) pathway, such as ATM, ATR, CHK1, and CHK2, that phosphorylate p53 on specific N-terminal amino acid residues (e.g., Ser15, Ser20, and Ser37) [68,69], leading to the displacement of MDM2 for p53 stabilization (Figure 1). In the context of DNA damage, 53BP1 has a crucial role in directing non-homologous end-joining or homologous recombination to remove double-strand breaks $[67,70]$. Despite its name (p53 Binding Protein 1) and the presence of a domain at the c-terminus that can actually interact with p53, the importance of the interaction between p53 and 53BP1 remained uncertain [67]. More recently, it has been demonstrated that 53BP1, in concert with USP28, directly tunes p53 transcriptional activity in response to DNA damage independently of its function in promoting DNA repair [71]. Nevertheless, 53BP1 KO, as well as USP28 KO cells, retain p53 stabilization in response to the DNA-damage-inducing agent doxorubicin, while phosphorylation of p53 on Ser15 does not occur in cells experiencing extended mitotic duration [65]. Overall, this suggests that, despite the involvement of the same actors, the downstream effects imposed by p53 in order to control cell fate could diverge in response to DNA damage and extended mitotic duration, given the different mechanisms and interactors that lead to p53 stabilization and activation.

Maybe unsurprisingly, the accumulation of extra centrosomes, e.g., as experienced by cells after defective cytokinesis, utilizes yet again a different machinery to activate p53, limiting their expansion or survival [72]. Here, a multiprotein complex, dubbed the PIDDosome [73], is engaged to promote the activation of a cysteine-driven protease, caspase-2, that can cleave MDM2, to neutralize this E3-ligase and enable p53 stabilization. Of note, the N-terminal fragment of MDM2, devoid of its E3-ligase domain, remains attached to p53, and phosphorylation events noted during the DDR are not seen upon centrosome accumu- 
lation [72], again pointing towards qualitative and potentially quantitative differences in this type of p53 response (Figure 1).

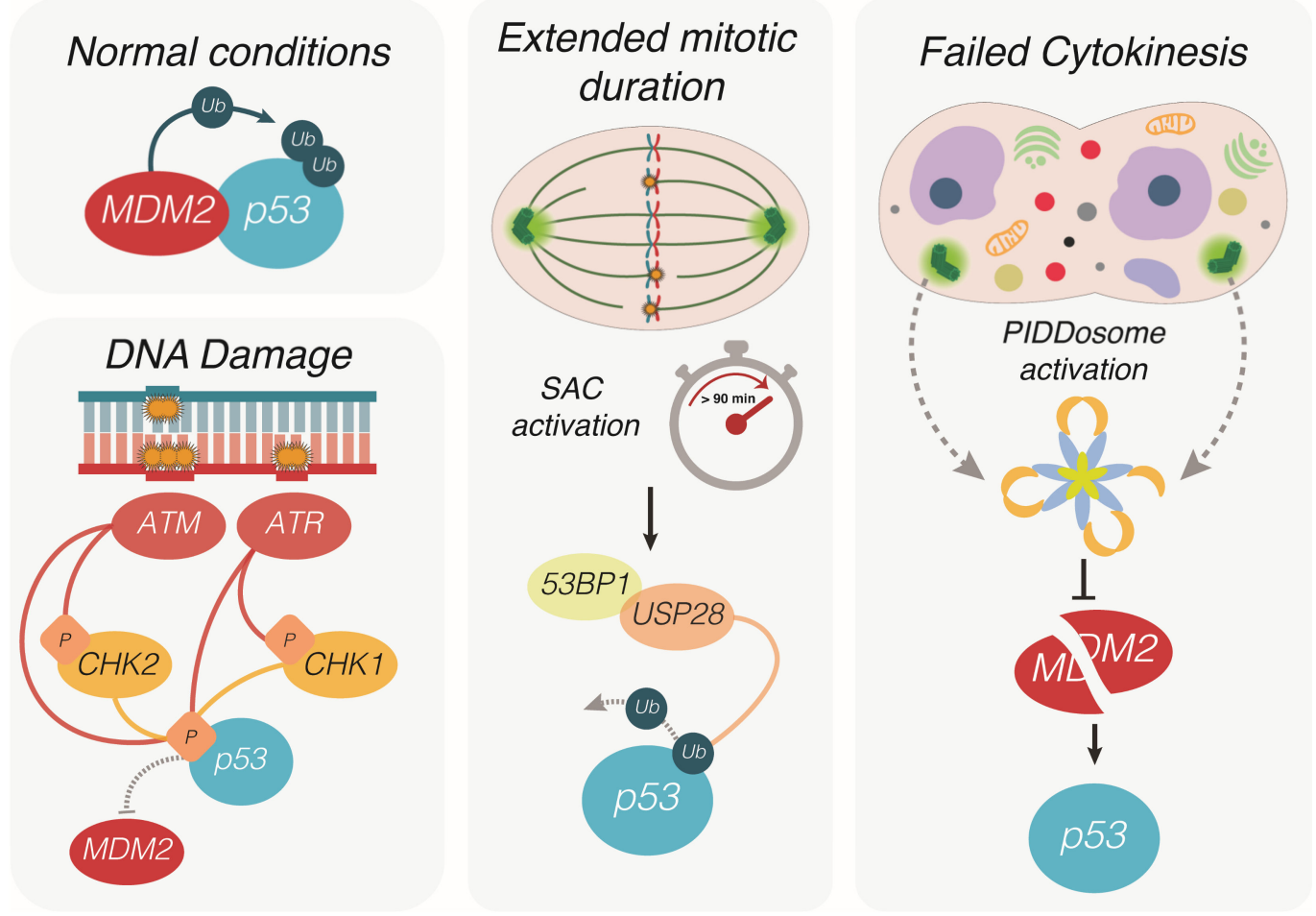

Figure 1. Different routes leading to 553 activation. In physiological conditions, p53 is bound and ubiquitinated by its negative regulator MDM2, which prevents nuclear translocation and promotes its proteasomal degradation. Upon single strand or double strand DNA damage, the kinases ATR and ATM activate the checkpoint kinases Chk1 and Chk2, which contribute to p53 phosphorylation on specific amino acidic residues. Phosphorylated p53 can no longer be bound and degraded by MDM2, resulting in protein stabilization, nuclear translocation and the activation of its transcriptional program. During mitosis, prolonged prometaphase due to the activation of the spindle assembly checkpoint (SAC) is sensed by 53BP1 and USP28. The latter protein promotes de-ubiquitination of p53, arresting the cell cycle in the next interphase. Defective cytokinesis prevents daughter cells to separate completely at the end of mitosis, resulting in a single polyploid cell containing extra centrosomes. The multiprotein complex PIDDosome senses the presence of extra centrosomes and functions as an activating platform for caspase-2. Being a target of this protease, MDM2 is cleaved and thereby inactivated, resulting in the accumulation of p53 and cell cycle arrest of the polyploid cell.

\section{P53-Induced Cell Cycle Arrest and Senescence}

As stated previously, the induction of cell cycle arrest appears intuitively helpful to prevent the outgrowth of a cell that has lost genome integrity, but this response, even in its most stringent form (i.e., senescence) appears to be overcome eventually during transformation or tumor therapy.

The potent cyclin-dependent kinase inhibitor $p 21$ (CDKN1A) was the first transcriptional target of p53 to be identified as capable of regulating tumor growth upon p53 activation [12]. As other genes connected to the control of cell cycle, the CDKN1A locus contains two strong p53 response elements (at -2.3 and $-1.4 \mathrm{~kb}$ from the transcription start site [74]), which allow a quick transcriptional upregulation of the CDKN1A gene upon p53 activation. The immediate result of p21 expression is the arrest of the cell cycle, which occurs via a p21-mediated inhibition of the cyclin/CDK complexes by physical interaction [21]. Inactivation of the cyclinE/A-CDK2 and cyclinD-CDK4/ 6 complexes prevents $\mathrm{CDK}$-mediated phosphorylation of $\mathrm{pRB}$, preventing the release of $\mathrm{E} 2 \mathrm{~F}$ transcription 
factors controlling the transition from $\mathrm{G} 1$ to the $\mathrm{S}$ phase $[75,76]$ (Figure 2). Yet, by looking at the p53 core transcriptional program, additional genes besides CDKN1A appear to be related to cell cycle control [77]. Of note, GADD45A is known to act in concert with p21 and SFN (also known as 14-3-3- $\sigma$, another p53 transcriptional target) to inhibit the cyclin B1/CDK1 complex necessary for entry into mitosis [78,79]. In addition, p53 induces PLK2 and PLK3 that encode kinases belonging to the polo-like family, both of which play important roles in the maintenance of genome integrity in response to mitotic errors and DNA damage [80] (Figure 2). Moreover, a number of p53 targets that may indirectly impinge on cell cycle control have been reported, including DUSP14, CyclinG1, BTG2, NUPR1, ZMAT3, and ZNF385A.

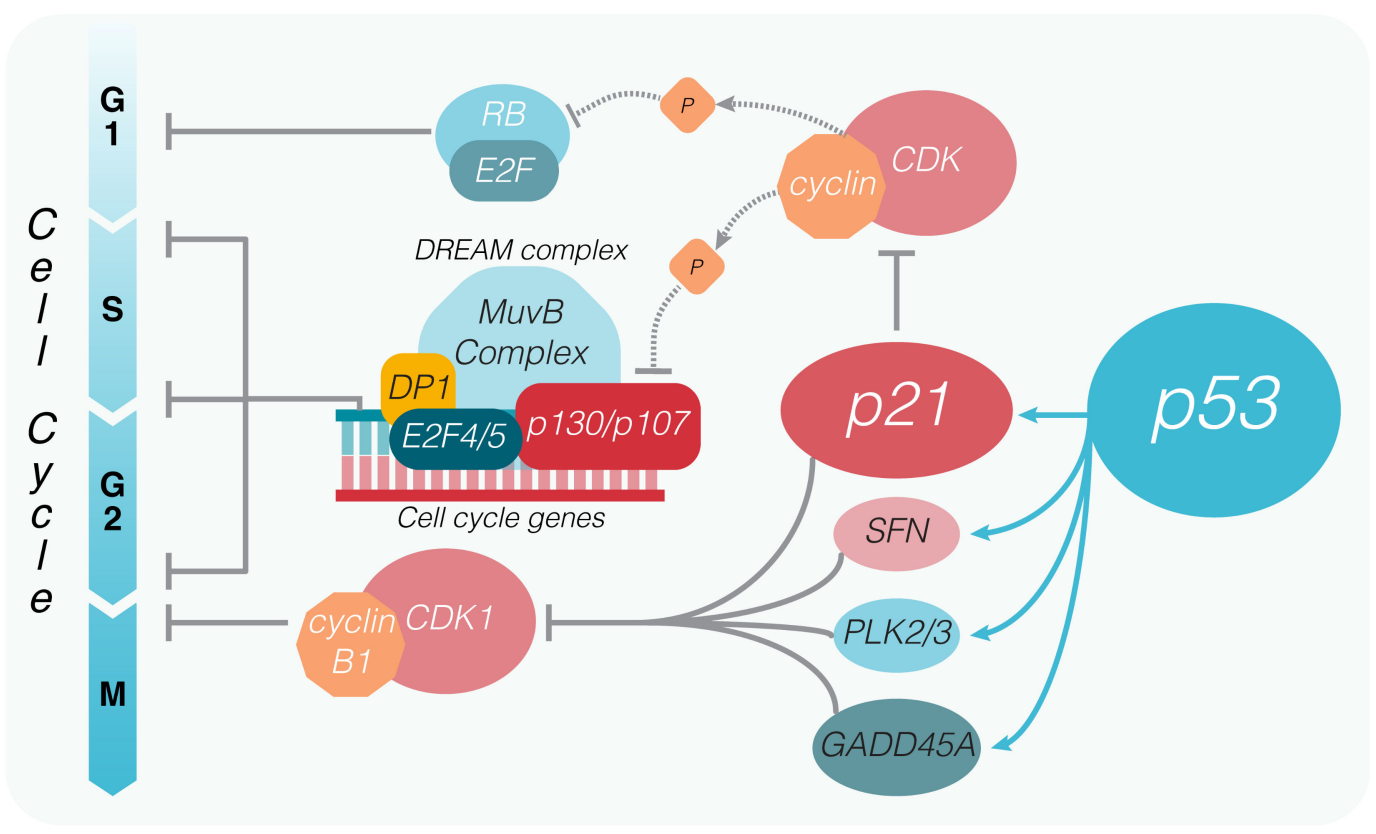

Figure 2. Cell cycle arrest imposed by p53. P53 controls the cell cycle via different routes by promoting the transcription of multiple targets, among which there are p21, SFN (14-3-3- $\sigma)$, GADD45A and the Polo like kinases (PLK) 2 and 3. The latter proteins contribute to the inhibition of the Cyclindependent kinase 1 (CDK1), which upon binding to cyclin B1 promotes mitotic entry. P21 inhibits the formation of cyclinE/A-CDK2 and cyclinD-CDK4/6 complexes, which control the entry into the S phase by phosphorylating the retinoblastoma (pRB) protein. The p21-dependent inhibition of cyclinCDK complexes also results in hyperphosphorylation of the retinoblastoma related pocket proteins p130/p107, keeping the DREAM complex in its inhibitory state, thus preventing the expression of multiple other genes responsible for cell cycle progression.

Besides transcriptional upregulation, high-throughput studies on cell lines exposed to p53 activating treatments repeatedly identified a plethora of genes whose expression was downregulated. Initially, it was considered that p53 could directly dampen the expression of these genes; therefore, different models that could explain the repressive mechanism have been proposed. Nevertheless, experimental evidence from ChIP data failed to determine a direct connection between p53 binding to a DNA sequence on a given gene and a subsequent reduction in mRNA production [7].

\section{P53 and the DREAM Complex}

The discovery of the DREAM complex was crucial to disentangle the mechanisms of p53-mediated target gene repression, which are now considered to be exclusively indirect through DREAM [77,81,82] and strictly dependent on the presence of p21 [83]. The DREAM complex (dimerization partner (DM), RB-like, E2F, and multi-vulval class B (MuvB)) is multiprotein machinery that, depending on the subunits interacting with the MuvB core, can 
bind with different regulatory elements on the promoter of target genes and, importantly, can act both as a transcriptional activator or repressor in a context-dependent manner [84]. A detailed review of the DREAM complex can be found in [85]. In physiological settings, cells are held in G1 (or G0) by the MuvB interacting with the pocket proteins p107 and p130, both of which are structurally and functionally related to pRB that bind, in turn, the repressor E2F4/5 (DREAM complex), resulting in downregulation of pro-proliferative E2F-responsive genes (Figure 2). Upon phosphorylation of p107/p130 by the cyclin/CDK complexes, the interaction with the MuvB core is terminated, allowing MuvB to bind B-MYB and/or FOXM1, forming the MMB (bMyb-MuvB) or the MMB-FOXM1 complexes. The latter complexes promote the transcription of target genes responsible for cell cycle progression through S, G2, and M phases [86,87]. Conversely, following p53 activation, p21-dependent inactivation of cyclin/CDKs complexes prevents the phosphorylation of p107/p130, arresting the switch from DREAM to MMB/MMB-FOXM1 complexes and repressing the transcription of target genes [88]. In this way, p53 indirectly downregulates the expression of several genes involved in DNA replication, the G2 checkpoint, and mitosis, expanding its cell cycle regulating potential beyond the simple induction of GADD45A, $\mathrm{SNF}$, and PLK2.

P53-induced senescence is considered a stable form of cycle arrest that involves alterations in cell metabolism, gene expression, and chromatin composition and association with a specific senescence-associated secretory phenotype (defined SASP) [89]. Induction of senescence is considered a multistep process, in which the initial cell cycle arrest is exerted by p21, becoming permanent via the subsequent activation of the CDK inhibitor p16/INK4a [89]. Intriguingly, p53-induced senescence could also be reverted upon p53 inactivation and, more effectively, upon pRB inactivation [90-92]. Overall, cellular senescence seems to be a dynamic phenotype, whether it is p53-dependent or not [93]. Similar to transient cell cycle arrest, the DREAM complex contributes to p53-induced senescence. It was initially discovered that RNAi-mediated downregulation of the DREAM complex proteins LIN9, LIN54, and B-MYB results in premature senescence through activation of p53 in human fibroblasts. Moreover, interfering with the phosphorylation of LIN52 (a protein composing the MuvB core) by downregulation of the kinase DYRK1A prevents the switch of the MuvB core from activating to the cell cycle-repressive DREAM state, impinging the cells' ability to enter senescence [94].

Of note, knock-down of LIN9 in human fibroblasts in combination with p53 inactivation via SV40 results in high levels of aneuploidy [95]. A similar result was also observed in LIN9-deficient mouse embryonic fibroblasts (MEFs) that displayed a high degree of polyploidization, binucleation, and other nuclear abnormalities $24 \mathrm{~h}$ after cell cycle re-entry, which ultimately led to premature senescence [96]. These aberrations arise from defective cell division, such as prolonged mitotic timing, failed cytokinesis, acquisition of extra centrosomes, and formation of multipolar spindles in subsequent rounds of cell division. Not surprisingly, impairing the DREAM complex formation interferes with the cell division process, as the expression of many genes responsible for mitosis are controlled by the MuvB core in the repressor (DREAM) or activator (B-MYB/FOXM1) conformation. However, the high degree of aneuploidy reached by LIN9-deficient MEFs raises the question whether the activation of p53 and p21 (PIDDosome- and/or USP28-53BP1-dependent) is sufficient for preventing tumorigenesis and to what extent the downstream activation of p21 and DREAM is essential to prevent the outgrowth of multinucleated and/or aneuploid cells.

Recently, an interesting feedback loop was discovered that also connects the PIDDosome to the p53-p21 axis and cell cycle control. Indeed, besides being regulated by p53 (as PIDD1 is a transcriptional target of p53 itself [97]), Sladky et al. discovered that during normal liver development or during regeneration, transcription factors of the E2F family control the expression of PIDD1 and CASP2. In this context, E2F1 promotes cell cycle progression as well as the upregulation of CASP2 and PIDD1, which limit the polyploidization of liver cells. Conversely, E2F7 and E2F8 have an opposing role, reducing 
the expression of the PIDDosome components and allowing hepatocytes to reach their physiological polyploid status [98].

\section{P53-Induced Apoptosis}

Apoptosis is the best-characterized form of p53-induced cell death (reviewed in [8]). Several transcriptional targets of $\mathrm{p} 53$ are tied to the intrinsic mitochondrial or extrinsic death receptor (DR)-driven apoptotic pathways $[77,99]$. While differing in trigger and execution, both pathways depend on cysteine-aspartic proteases termed caspases to coordinate nonimmunogenic apoptosis.

Certain cytotoxic insults such as DNA damage caused by UV or ionizing radiation can activate the intrinsic apoptotic pathway through the p53-driven expression of pro-apoptotic members of the BCL2 protein family [25,100-103]. Being comprised of pro-survival- and pro-apoptotic proteins, the BCL2 family members keep each other in check through direct protein-protein interactions mediated through their shared BH (BCL-2 homology) domains (reviewed in [104]). Pro-survival members, such as BCL2, BCLX, and MCL1, bind and sequester pro-apoptotic "BH3-only" proteins, including BID, PUMA, and NOXA, impairing their ability to activate the apoptosis effector proteins BAX and BAK [105] (Figure 3). Amongst these apoptosis regulators, well-characterized p53 transcriptional targets include the BH3-only proteins PUMA/BBC3 [100], NOXA/PMAIP1 [103] and potentially BID [106], as well as the apoptosis effector $B A X[107,108]$. These findings imply that p53 activity has direct consequences on apoptosis induction as its transcription of pro-apoptotic genes contributes to surpassing the apoptotic threshold.

Additionally, p53 may trigger apoptosis at mitochondria independently of transcription through direct protein-protein interactions. These include the direct engagement of mitochondria and binding of the pro-survival proteins BCL2 and BCLX $[109,110]$. Cytosolic p53 was further reported to directly activate BAX [111] and BAK upon mitochondrial translocation [112]. Mechanistically, p53's cytosolic pro-apoptotic function upon genotoxic stress has been suggested to be regulated through the transcription of its target gene PUMA, which in turn disrupts cytosolic BCLX/p53 complexes by competitive binding [111,113]. p53 binding of BCLX is meanwhile supported by crystal structure data [114] and has been successfully targeted in glioblastoma xenograft models to induce apoptosis [115]. Its interaction with the apoptosis effectors BAX and BAK, however, has been mainly addressed with recombinant protein studies or in overexpression settings. While these findings are intriguing, they remain controversial, as physiological settings where $\mathrm{p} 53^{\prime} \mathrm{s}$ direct protein-protein interactions become rate-limiting for intrinsic apoptosis remain to be uncovered.

Once activated, BAX and BAK homo-oligomerize in the outer mitochondrial membrane, leading to the release of apoptotic mediators, including cytochrome $\mathrm{c}$ and caspasederepressing proteins. In the cytoplasm, cytochrome c interacts with APAF1 to promote the formation of the apoptosome, the activation platform of initiator caspase-9. Active caspase- 9 can then proteolytically activate executioner caspases (caspase-3, -6, -7), which orchestrate the breakdown of the cell. Intriguingly, p53 seems to tune apoptosis by regulating APAF1 expression $[116,117]$. Conversely, the p53-induced apoptosis inhibitor TRIAP1 has been reported to interfere with apoptosome formation [118,119] (Figure 3).

Extrinsic apoptosis is elicited by DRs that are transmembrane-signaling molecules belonging to the tumor necrosis factor receptor (TNFR) superfamily (reviewed in [120]). P53 also intersects this pathway as it can regulate the expression of several DRs. This includes Fas (CD95/APO-1) [121] and the TRAIL receptors 1 (DR4/TNFRSF10A) [122] and 2 (DR5/KILLER/TNFRSF10B) [123] that, respectively, bind the apoptosis-initiating ligands FasL and TRAIL (TNF-related apoptosis-inducing ligand). Ligand binding clusters these receptors, thereby forming signaling scaffolds via their specialized intracellular death domains (DD). These domains allow the recruitment of adaptor proteins such as FADD (Fas-associated death domain), forming a death-inducing signaling complex (DISC), which serves as an activation platform for the initiator caspases 8 and 10 [124-126]. In a cell- 
type-specific manner, these initiators can directly cleave and activate effector caspases (e.g., in lymphocytes) or drive apoptosis via the engagement of the mitochondrial apoptotic pathway (e.g., in hepatocytes). The latter is mediated by the BH3-only protein BID, a reported p53 target, which is truncated and activated by caspase-8 $[127,128]$ (Figure 3). On the contrary, through its transcriptional control of the DD lacking decoy receptors TRAIL receptor 3 (TRID/TNFRSF10C) and 4 (TRUNDD/TNFRSF10D), p53 has also been reported to negatively regulate apoptosis $[129,130]$.
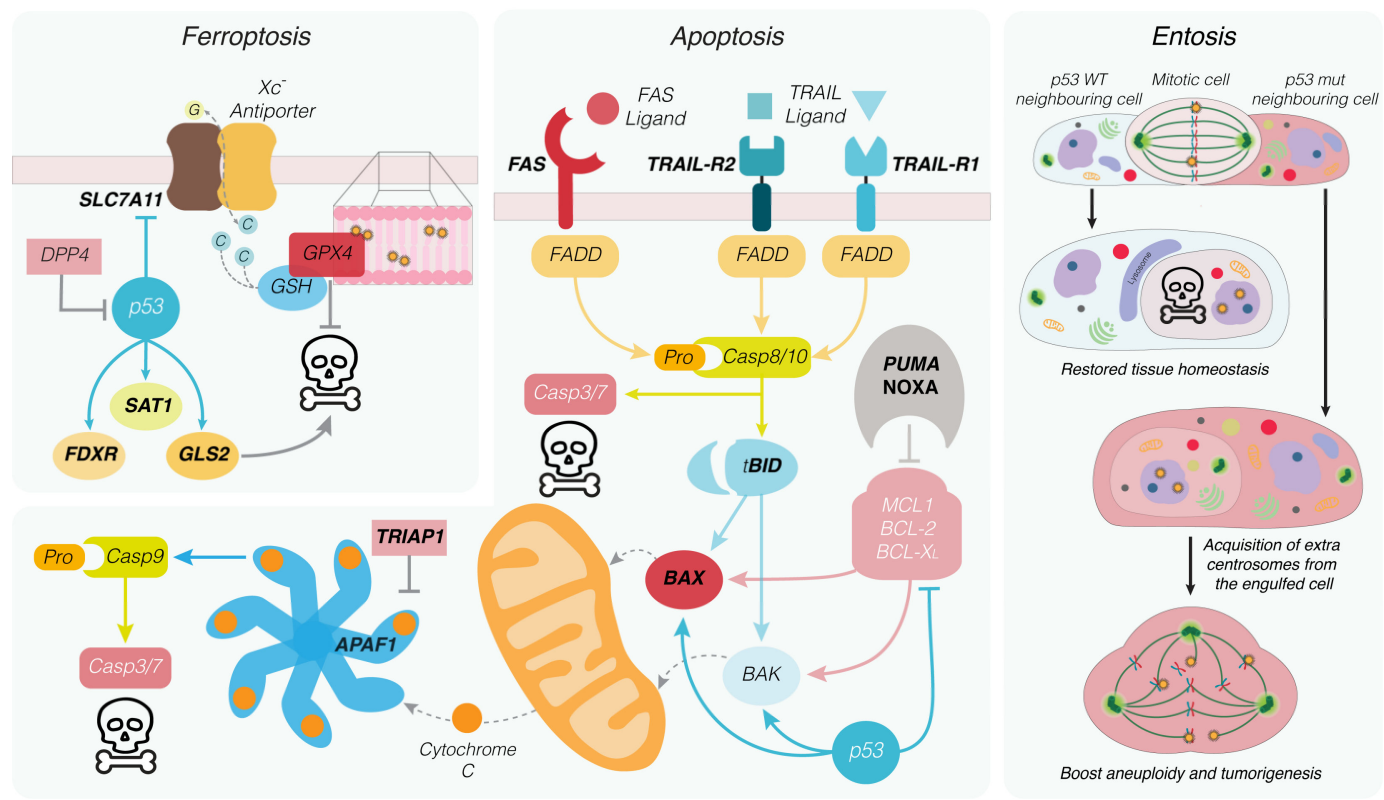

Figure 3. Critical p53-regulated cell death modalities. Upon alterations of the cellular redox state, iron-dependent peroxidation of membrane phospholipids can occur, promoting ferroptosis. Peroxidation can be reversed by the selenocysteinecontaining protein glutathione peroxidase 4 (GPX4) in a glutathione (GSH)-dependent manner. By inhibiting the transcription of the system $\mathrm{Xc}^{-}$complex subunit SLC7A11, p53 reduces the reservoir of cysteine (C) necessary for GSH synthesis, thus preventing reversion of lipid peroxidation. Moreover, p53 controls the transcription of FDXR, SAT1 and GLS2, favouring cell death via ferroptosis. Extrinsic apoptosis is initiated by e.g. FAS or TRAIL ligand binding to their cognate receptors promoting the multimerization of receptor trimers. These form the cell death inducing signalling complex (DISC) that recruits the adapter protein FADD, which promotes activation of the initiator caspase-8, which activates in turn executioner caspases-3 and -7, alongside the BCL2 family protein BID. Intrinsic apoptosis depends solely on the balance between the inhibitory (e.g. MCL1, BCL2, BCLX) and the apoptosis-promoting members of the BCL2 family. Regardless of the apoptotic route, BAX and BAK homo-oligomerization in the mitochondrial outer membrane results in release of cytochrome $\mathrm{C}$, which complexes to APAF1 forming the apoptosome. This multiprotein complex allows dimerization of the initiator caspase-9, which in turn activates the cytosolic executioner caspases-3 and -7, leading to cell death. Cells experiencing defective mitosis are prone to form cell in cell $(\mathrm{CiC})$ structures with neighbouring cells in a process called entosis. In a p53 wildtype context, the internalized cell is killed by lysosomal degradation, preventing the outgrowth of defective cells. On the contrary, entosis fosters tumorigenesis in p53 mutated cells by interfering with the mitotic process of the internalizing cell and promoting aneuploidy. Direct transcriptional targets of p53 are labelled in bold.

Albeit the transcriptional activation of DR family proteins by p53 remains undisputed, its role in apoptosis in response to genotoxic stress in cancer versus normal cells remains to be fully understood. It remains plausible that the expression of these TNFR family proteins by p53 contributes to sterile inflammatory signaling after cells experience DNA damage or undergo mitotic errors.

\section{Non-Apoptotic Cell Death Forms Regulated by p53}

Entosis is a form of non-apoptotic cell death in which one cell invades another, forming a cell-in-cell $(\mathrm{CiC})$ structure. The presence of these structures has been noted in 
histological examination of tumor specimens at the end of the nineteenth century. It can involve different types of cells (both in terms of tissue derivation and oncogenic status) but not professional phagocytes [131,132]. Mechanistically, entosis requires actomyosin rearrangements that are driven by the GTPase RhoA and the effectors ROCK1 and ROCK2. Cytoskeletal rearrangements on the internalizing cell push it towards the future host, and the invasion process requires adherent junction formation between the entotic and the host cell [133]. Once internalized, most entotic cells undergo cell death by a mechanism involving their lysosomal degradation. However, sometimes, cells are either released from or remain alive within the host for extended periods of time [133]. This can interfere with the host cell division cycle and ultimately lead to aneuploidy [134]. Consistently, entosis can be either tumor-suppressive or -promoting, as the internalized cell can undergo cell death but also interfere with normal cell division of the host, promoting aneuploidy. More recent reports identified how the p53 status of the invaded host can discriminate the proor anti-tumorigenic aspect of entosis. Mackay and colleagues [135] identified how a host cell bearing mutant p53 is more prone to form $\mathrm{CiC}$ structures and take advantage of the engulfed cell to create genetic diversity via aneuploidy, while Durgan et al. determined how adherent epithelial cells undergoing mitotic defects (such as prolonged metaphase arrest and/or changes in mitotic morphology) are more prone to being internalized by neighboring healthy cells. This phenomenon can potentially prevent the outgrowth of cells bearing genomic defects [136] (Figure 3). Along this line, Liang et al. determined how entosis following mitosis is controlled by p53, which is activated upon the DNA damage experienced by the cell undergoing prolonged mitotic arrest. In this context, p53 directly upregulates the expression of its target $R n d 3$, which directs the function of the RhoA-ROCK1 pathway to remodel the actomyosin filaments promoting the penetration of neighboring cells [137]. In this case, prolonged mitosis and the activation of the 53BP1-USP28 axis is not responsible for entosis, suggesting that p53 controls two independent mechanisms aimed at preventing the growth of cells experiencing difficulties in metaphase: on the one hand, entosis and clearance by its neighbors, and on the other hand, the p21-mediated arrest in the next interphase [64-66]. If the 53BP1-USP28 axis can trigger p53-induced apoptosis in cells entering the G1 phase remains to be investigated.

Ferroptosis is a non-apoptotic, caspase-independent form of cell death caused by extensive iron-dependent lipid peroxidation [138]. By altering the intracellular redox balance, p53 can both induce and block ferroptosis (reviewed in [139]).Physiological amounts of oxygenated phospholipids in the plasma membrane are reduced by the glutathione peroxidase GPX4 to prevent ferroptosis [140]. Through transcriptionally repressing SLC7A11, p53 reduces available intracellular antioxidant levels and promotes oxidative damage, leading to ferroptosis induction [141]. SLC7A11 is part of the cystine/glutamate antiporter system $x_{c}{ }^{-}$that is essential for sustaining reduced glutathione pools. In vivo studies found that mice harboring an acetylation-deficient, mutated form of p53 (3KR), which renders them resistant to apoptosis, cell cycle arrest, and senescence, were still able to repress SLC7A11 and promote ferroptosis induction [141]. Moreover, mice expressing this 3KR p53 mutant and lacking the DNA damage repair gene XRCC4 were found to be viable (while XRCC4-deficient mice are not) and protected from spontaneous tumorigenesis, although showing high degrees of genomic instability [142]. As the authors found SLC7A11 downregulation and ferroptosis induction in these mice, they linked the regulation of ferroptosis to p53's function as a tumor suppressor (Figure 3). Another pro-ferroptotic gene controlled by p53 is the polyamine-metabolizing enzyme SAT1 [143]. SAT1 overexpression sensitizes cells to ferroptosis, possibly through its downstream effects on the lipoxygenase ALOX15 [143]. When overexpressed in tumor cells in xenograft models, SAT1 limits tumor growth through ferroptosis induction, which was later shown to be additionally dependent on the lipoxygenase ALOX12 [143,144]. These findings provide further evidence on ferroptosis as a tumor-suppressive effector arm of p53. Additional target genes involved in controlling this type of cell death include FDXR (ferredoxin reductase) [145] and GLS2 (glutaminase 2) [146]. Yet, as mentioned above, p53 serves antithetical 
functions in ferroptosis regulation, which may be explained by cell-type-specific pathway alterations or PTMs such as acetylation [147]. For example, in wildtype colorectal cancer cells, p53 was found to suppress erastin-induced ferroptosis in a transcription-independent manner. This was suggested to rely on sequestration of dipeptidyl peptidase 4 (DPP4) in the nucleus, thereby limiting membrane peroxidation [148]. Another recent study found that the long-term stabilization of p53 and transcription of the cell cycle inhibitor p21 markedly delayed ferroptosis onset upon blocking of system $\mathrm{x}_{\mathrm{c}}{ }^{-}$[149]. This delay required available, reduced glutathione pools, suggesting that cell cycle stage and metabolic activity timed by p53 affects a cell's susceptibility to undergoing ferroptosis [149]. Clearly, cell type and metabolic state will affect the outcome of p53-dependent changes in the signaling networks modulating ferroptosis susceptibility. Additional studies are needed to put these observations into context.

Mitosis is a tightly regulated process, as karyotype aberrations resulting from abnormal cell division can increase the susceptibility of daughter cells to malignant transformation (reviewed in [27]). To maintain genome integrity, the outgrowth of aneuploid and chromosomally instable cells is attenuated by processes summarized as mitotic catastrophe (reviewed in [150]). Caspase-2 has been promoted as a key executor in these pathways, which at least in part depend on p53 [151]. Caspase-2 has been implicated in a variety of biological functions, including apoptosis induced by DNA damage (reviewed in [152]). In this context, Tinel and Tschopp identified the PIDDosome as an activation platform of caspase-2 [73]. P53 activation has been seen as a crucial determinant of caspase-2-induced cell death, primarily through the transcriptional regulation of PIDD1 [97]. While mouse genetics did not support a decisive role for the PIDDosome in DNA damage $[153,154]$, in vitro studies provided evidence that caspase-2 can cleave MDM2, the master regulator of p53 protein levels, upon DNA damage, placing p53 simultaneously up and downstream of caspase-2 [155]. How can this conundrum be reconciled? As it seems, both scenarios can be true. The PIDDosome/MDM2/p53 axis is central in the response to centrosome accumulation, e.g., after cytokinesis failure [72], placing caspase-2 upstream of p53. Alternatively, PIDDosome-activated caspase- 2 has been proposed to act as a fail-safe mechanism by initiating a stable p53 response in cells that escape cell cycle arrest following DNA damage [156]. Here, caspase-2 may act as an important safeguard of genome integrity downstream of p53. Consistently, $\gamma$-irradiated caspase-2-null MEFs were found to fail to undergo apoptosis and continue cycling [157]. Furthermore, MEFs, as well as MYCinduced B cell lymphomas from mice lacking caspase-2, show defective p53 signaling and increased aneuploidy $[158,159]$. Yet, the role of caspase-2 in clearing aneuploid cells as well as potential mechanisms involved needs to be clarified in future studies.

The list of "non-canonical" forms of cell death with reported p53 involvement is long and extends beyond the ones discussed above, including also autophagic cell death (ACD) and paraptosis (reviewed in [160]). Unsurprisingly, ACD can be limited by the downregulation of autophagic genes [161]. One important modulator worth mentioning is the p53-induced gene DRAM1 that encodes a lysosomal sensor protein [162,163]. This transcriptional p53/DRAM-axis contributes to death induction upon ionizing radiation treatment in model cell lines [164]. Further studies report p53 phosphorylation and activation by MAP kinases following DR or TNFR stimulation, leading to the upregulation of autophagic executors, including DRAM or Beclin1 $[165,166]$. Consistently in both studies, p53 deficiency or inactivation rendered cells less susceptible to ACD. This will allow the correct placement of p53 in these pathways, considering its cross-talk with autophagy-defining mTOR signaling [167] and p53's regulation at the protein level by the core autophagic complex Beclin1/Vps34 [168].

Paraptosis is another form of programmed cell death that is insensitive to caspase inhibitors and morphologically defined by the swelling and vacuolization of the endoplasmic reticulum and mitochondria [169]. A link between p53 and paraptosis has been suggested as drug-induced vacuole formation decreased in p53 knockout cells [170]. In vivo studies supporting a role of paraptosis or ACD in disease are rare, but in a mouse model investi- 
gating Alzheimer disease phenotypes, mice expressing a transgene of the p53 isoform p44 and the amyloid precursor protein were found to suffer from neurodegeneration that was caspase- and apoptosis-independent and shared morphological features assigned to paraptosis and ACD [171]. Yet, paraptosis can be effectively induced in several p53-defective cancer cell lines [172], highlighting the need for further studies for clarification. While the diverse functional portfolio of p53 links it to many cell death pathways, it can be assumed that $\mathrm{p} 53^{\prime} \mathrm{s}$ function in some is more that of an indirect facilitator or amplifier.

\section{Life-Death Decisions by p53-Flicking the Switch}

What ultimately defines cell fate after p53 activation in diverse cell types? Over the years, different models have been proposed trying to explain how p53 imposes different phenotypes upon its activation, culminating in the re-entry into the cell cycle, the maintenance of an arrested phenotype (senescence), or the induction of cell death. As it seems, a consistent and universal predictor of the terminal phenotype is still to be determined or simply does not exist. Intuitively, the type of damage experienced by the cell, its severity, and duration in time can be crucial factors leading to either survival or death $[16,173]$. Indeed, an acute or sustained stressor will promote a higher magnitude of p53 activation or a sustained activation in time, which can result in the binding of weaker response elements, such as those situated on pro-apoptotic genes [9]. Nevertheless, this model does not hold universally true, e.g., cells belonging to different tissues show a different sensitivity towards the same p53-activating trigger $[174,175]$, hinting towards a more complex network regulating the choice between life and death.

Besides, p53 is a protein that is subject to extensive post-translational modifications, which are often connected to the activating route of p53 itself and influence its functions $[176,177]$. Nevertheless, to the same subset of post-translational modifications, a completely different phenotype can follow [178] or, conversely, different routes of activation (leading to a different subset of PTMs on p53) can converge into the same terminal phenotype. An example is the induction of apoptosis correlated to extensive DNA damage, which is associated with phosphorylation on Ser46 $[179,180]$. Nevertheless, Nultin-3 treatment, which does not induce Ser46 phosphorylation [181], is still able to trigger p53-dependent apoptosis [175], suggesting additional layers of decision making.

The discovery of the pulsatile nature of p53 activity over time [182] opens a different scenario in the determination of the choice between life and death, as cells showing an oscillating activation of p53 are more prone to repair DNA damage and survive, whereas a sustained p53 activation (either cell-type-specific or treatment-dependent) is associated with senescence [183] and ferroptosis resistance [149]. The oscillatory behavior observed is due to the feedback loop between p53 and MDM2 [182]. If cells slip out of the arrest and re-enter the cell cycle before the DNA damage is completely repaired, p53 is re-activated with sustained dynamics thanks to the action of the PIDDosome, which inactivates MDM2 upon completion of mitosis in the presence of unrepaired DNA damage and allows the establishment of sustained p53 activation [156]. Conversely, apoptosis is only induced upon a quicker induction of the protein compared to surviving cells and is triggered only in cells that reach a certain threshold of p53 accumulation [184,185]. Surprisingly though, activation dynamics do not influence the binding potential of the protein to its response elements [186], suggesting that phenotype decision occurs post-transcriptionally. This is in line with the findings of Andrysik and collaborators [77]: cell lines exposed to the same p53-activating stimulus but showing a different outcome to the treatment (i.e., cell death or apoptosis) share a nearly identical transcriptome (also comprising apoptotic modulators in cell-cycle-arresting cells). However, at the translatome level, the ensemble of mRNA that is actively translated changes dramatically between cell lines, where apoptosis mediators are bound to ribosomes and translated much before apoptosis onset in sensitive cells [77]. The translatome of apoptotic cells is strongly influenced by the intrinsic repertoire of RNA-binding proteins (RBPs) that are present in those cells, shaping the phenotype at a post-transcriptional level [187]. Intriguingly, p53 itself can directly participate to 
post-transcriptional gene regulation by controlling the transcription of many RBPs and microRNAs [188,189].

\section{Conclusions}

p53 is at the center of a branching network of effector programs, including cell cycle arrest, senescence, and various forms of cell death. How exactly p53 makes the decision of which program to initiate remains elusive but is at least in part stimulus- and cell type-dependent. As the complexity of the p53 responses observed and the network of players is constantly growing and is far from being disentangled, research on the most studied tumor-suppressor gene needs to continue to provide satisfactory context- and cell-type-dependent answers that will eventually help to harness p53 for cancer treatment.

Funding: Work in our laboratory is currently supported by the Austrian Science Fund, FWF (P 29499), the Austrian Academy of Sciences (OeAW), the Ludwig Boltzmann Society (LBG), and the ERC-AdG "POLICE" (\#787171).

Institutional Review Board Statement: Not applicable.

Informed Consent Statement: Not applicable.

Data Availability Statement: Not applicable.

Acknowledgments: Research on p53 and the PIDDosome in our laboratory is supported by the Austrian Academy of Sciences (ÖAW) and the ERC AdG_POLICE (\#787171).

Conflicts of Interest: The authors declare no conflict of interest.

$\begin{array}{ll}\text { Abbreviations } \\ \text { ACD } & \text { autophagic cell death } \\ \text { BH } & \text { BCL2 homology } \\ \text { ChIP } & \text { chromatin immunoprecipitation } \\ \text { CiC } & \text { cell-in-cell structure } \\ \text { CIN } & \text { chromosomal instability } \\ \text { DD } & \text { death domain } \\ \text { DDR } & \text { DNA damage response } \\ \text { DR } & \text { death receptor } \\ \text { MEF } & \text { mouse embryonic fibroblast } \\ \text { PTM } & \text { post-translational modifications } \\ \text { RBP } & \text { RNA binding proteins } \\ \text { SAC } & \text { spindle assembly checkpoint } \\ \text { SNP } & \text { single-nucleotide polymorphism } \\ \text { TNFR } & \text { tumor necrosis factor receptor }\end{array}$

\section{References}

1. Báez, A. Genetic and Environmental Factors in Head and Neck Cancer Genesis. J. Environ. Sci. Health Part C 2008, 26, 174-200. [CrossRef] [PubMed]

2. Landi, S. Genetic Predisposition and Environmental Risk Factors to Pancreatic Cancer: A Review of the Literature. Mutat. Res./Rev. Mutat. Res. 2009, 681, 299-307. [CrossRef] [PubMed]

3. Moore, E.E.; Wark, J.D.; Hopper, J.L.; Erbas, B.; Garland, S.M.; CeCaGeEn Study Group. The Roles of Genetic and Environmental Factors on Risk of Cervical Cancer: A Review of Classical Twin Studies. Twin Res. Hum. Genet. 2012, 15, 79-86. [CrossRef]

4. Nickels, S.; Truong, T.; Hein, R.; Stevens, K.; Buck, K.; Behrens, S.; Eilber, U.; Schmidt, M.; Häberle, L.; Vrieling, A.; et al. Evidence of Gene-Environment Interactions between Common Breast Cancer Susceptibility Loci and Established Environmental Risk Factors. PLoS Genet. 2013, 9, e1003284. [CrossRef] [PubMed]

5. Rahman, M.S.; Suresh, S.; Waly, M.I. Risk Factors for Cancer: Genetic and Environment. In Bioactive Components, Diet and Medical Treatment in Cancer Prevention; Waly, M.I., Rahman, M.S., Eds.; Springer International Publishing: Cham, Switzerland, 2018; pp. 1-23. ISBN 978-3-319-75692-9.

6. Rudolph, A.; Chang-Claude, J.; Schmidt, M.K. Gene-Environment Interaction and Risk of Breast Cancer. Br. J. Cancer 2016, 114, 125-133. [CrossRef] 
7. Sullivan, K.D.; Galbraith, M.D.; Andrysik, Z.; Espinosa, J.M. Mechanisms of Transcriptional Regulation by P53. Cell Death Differ. 2018, 25, 133-143. [CrossRef]

8. Aubrey, B.J.; Kelly, G.L.; Janic, A.; Herold, M.J.; Strasser, A. How Does P53 Induce Apoptosis and How Does This Relate to P53-Mediated Tumour Suppression? Cell Death Differ. 2018, 25, 104-113. [CrossRef]

9. Chen, J. The Cell-Cycle Arrest and Apoptotic Functions of P53 in Tumor Initiation and Progression. Cold Spring Harb. Perspect. Med. 2016, 6, a026104. [CrossRef]

10. Hofseth, L.J.; Hussain, S.P.; Harris, C.C. P53: 25 Years after Its Discovery. Trends Pharmacol. Sci. 2004, 25, 177-181. [CrossRef]

11. Kastenhuber, E.R.; Lowe, S.W. Putting P53 in Context. Cell 2017, 170, 1062-1078. [CrossRef]

12. El-Deiry, W.S.; Tokino, T.; Velculescu, V.E.; Levy, D.B.; Parsons, R.; Trent, J.M.; Lin, D.; Mercer, W.E.; Kinzler, K.W.; Vogelstein, B. WAF1, a Potential Mediator of P53 Tumor Suppression. Cell 1993, 75, 817-825. [CrossRef]

13. Amaral, J.D.; Xavier, J.M.; Steer, C.J.; Rodrigues, C.M. The Role of P53 in Apoptosis. Discov. Med. 2010, 9, $145-152$.

14. Bieging, K.T.; Mello, S.S.; Attardi, L.D. Unravelling Mechanisms of P53-Mediated Tumour Suppression. Nat. Rev. Cancer 2014, 14, 359-370. [CrossRef] [PubMed]

15. Humpton, T.; Vousden, K.H. Taking up the Reins of Power: Metabolic Functions of P53. J. Mol. Cell Biol. 2019, 11, 610-614. [CrossRef]

16. Vousden, K.H.; Prives, C. Blinded by the Light: The Growing Complexity of P53. Cell 2009, 137, 413-431. [CrossRef] [PubMed]

17. Li, T.; Kon, N.; Jiang, L.; Tan, M.; Ludwig, T.; Zhao, Y.; Baer, R.; Gu, W. Tumor Suppression in the Absence of P53-Mediated Cell-Cycle Arrest, Apoptosis, and Senescence. Cell 2012, 149, 1269-1283. [CrossRef]

18. Valente, L.J.; Gray, D.H.D.; Michalak, E.M.; Pinon-Hofbauer, J.; Egle, A.; Scott, C.L.; Janic, A.; Strasser, A. P53 Efficiently Suppresses Tumor Development in the Complete Absence of Its Cell-Cycle Inhibitory and Proapoptotic Effectors P21, Puma, and Noxa. Cell Rep. 2013, 3, 1339-1345. [CrossRef]

19. Aylon, Y.; Oren, M. P53: Guardian of Ploidy. Mol. Oncol. 2011, 5, 315-323. [CrossRef]

20. Gronroos, E.; López-García, C. Tolerance of Chromosomal Instability in Cancer: Mechanisms and Therapeutic Opportunities. Cancer Res. 2018, 78, 6529-6535. [CrossRef]

21. Abbas, T.; Dutta, A. P21 in Cancer: Intricate Networks and Multiple Activities. Nat. Rev. Cancer 2009, 9, 400-414. [CrossRef]

22. Dansen, T.B.; Whitfield, J.; Rostker, F.; Brown-Swigart, L.; Evan, G.I. Specific Requirement for Bax, Not Bak, in Myc-Induced Apoptosis and Tumor Suppression in Vivo. J. Biol. Chem. 2006, 281, 10890-10895. [CrossRef]

23. Eischen, C.M.; Roussel, M.F.; Korsmeyer, S.J.; Cleveland, J.L. Bax Loss Impairs Myc-Induced Apoptosis and Circumvents the Selection of P53 Mutations during Myc-Mediated Lymphomagenesis. Mol. Cell. Biol. 2001, 21, 7653-7662. [CrossRef] [PubMed]

24. Hemann, M.T.; Zilfou, J.T.; Zhao, Z.; Burgess, D.J.; Hannon, G.J.; Lowe, S.W. Suppression of Tumorigenesis by the P53 Target PUMA. Proc. Natl. Acad. Sci. USA 2004, 101, 9333-9338. [CrossRef] [PubMed]

25. Michalak, E.M.; Jansen, E.S.; Happo, L.; Cragg, M.S.; Tai, L.; Smyth, G.K.; Strasser, A.; Adams, J.M.; Scott, C.L. Puma and to a Lesser Extent Noxa Are Suppressors of Myc-Induced Lymphomagenesis. Cell Death Differ. 2009, 16, 684-696. [CrossRef] [PubMed]

26. Valente, L.J.; Grabow, S.; Vandenberg, C.J.; Strasser, A.; Janic, A. Combined Loss of PUMA and P21 Accelerates C-MYC-Driven Lymphoma Development Considerably Less than Loss of One Allele of P53. Oncogene 2016, 35, 3866-3871. [CrossRef]

27. Giam, M.; Rancati, G. Aneuploidy and Chromosomal Instability in Cancer: A Jackpot to Chaos. Cell Div. 2015, 10, 3. [CrossRef] [PubMed]

28. Sanchez, Y.; Wong, C.; Thoma, R.S.; Richman, R.; Wu, Z.; Piwnica-Worms, H.; Elledge, S.J. Conservation of the Chk1 Checkpoint Pathway in Mammals: Linkage of DNA Damage to Cdk Regulation Through Cdc25. Science 1997, 277, 1497-1501. [CrossRef]

29. Faesen, A.C.; Thanasoula, M.; Maffini, S.; Breit, C.; Müller, F.; van Gerwen, S.; Bange, T.; Musacchio, A. Basis of Catalytic Assembly of the Mitotic Checkpoint Complex. Nature 2017, 542, 498-502. [CrossRef]

30. Maresca, T.J.; Salmon, E.D. Welcome to a New Kind of Tension: Translating Kinetochore Mechanics into a Wait-Anaphase Signal. J. Cell Sci. 2010, 123, 825-835. [CrossRef] [PubMed]

31. Holland, A.J.; Cleveland, D.W. Boveri Revisited: Chromosomal Instability, Aneuploidy and Tumorigenesis. Nat. Rev. Mol. Cell Biol. 2009, 10, 478-487. [CrossRef]

32. Levine, M.S.; Holland, A.J. The Impact of Mitotic Errors on Cell Proliferation and Tumorigenesis. Genes Dev. 2018, 32, 620-638. [CrossRef]

33. Nigg, E.A.; Holland, A.J. Once and Only Once: Mechanisms of Centriole Duplication and Their Deregulation in Disease. Nat. Rev. Mol. Cell Biol. 2018, 19, 297-312. [CrossRef]

34. Thompson, S.L.; Bakhoum, S.F.; Compton, D.A. Mechanisms of Chromosomal Instability. Curr. Biol. 2010, 20, R285-R295. [CrossRef]

35. Williams, B.R.; Prabhu, V.R.; Hunter, K.E.; Glazier, C.M.; Whittaker, C.A.; Housman, D.E.; Amon, A. Aneuploidy Affects Proliferation and Spontaneous Immortalization in Mammalian Cells. Science 2008, 322, 703-709. [CrossRef] [PubMed]

36. Ben-David, U.; Amon, A. Context Is Everything: Aneuploidy in Cancer. Nat. Rev. Genet. 2020, 21, 44-62. [CrossRef]

37. Sansregret, L.; Vanhaesebroeck, B.; Swanton, C. Determinants and Clinical Implications of Chromosomal Instability in Cancer. Nat. Rev. Clin. Oncol. 2018, 15, 139-150. [CrossRef]

38. Chunduri, N.K.; Storchová, Z. The Diverse Consequences of Aneuploidy. Nat. Cell Biol. 2019, 21, 54-62. [CrossRef] [PubMed] 
39. Ohashi, A.; Ohori, M.; Iwai, K.; Nakayama, Y.; Nambu, T.; Morishita, D.; Kawamoto, T.; Miyamoto, M.; Hirayama, T.; Okaniwa, M.; et al. Aneuploidy Generates Proteotoxic Stress and DNA Damage Concurrently with P53-Mediated Post-Mitotic Apoptosis in SAC-Impaired Cells. Nat. Commun. 2015, 6, 7668. [CrossRef]

40. Pfau, S.J.; Silberman, R.E.; Knouse, K.A.; Amon, A. Aneuploidy Impairs Hematopoietic Stem Cell Fitness and Is Selected against in Regenerating Tissues in Vivo. Genes Dev. 2016, 30, 1395-1408. [CrossRef] [PubMed]

41. Herrero, A.B.; Rojas, E.A.; Misiewicz-Krzeminska, I.; Krzeminski, P.; Gutiérrez, N.C. Molecular Mechanisms of P53 Deregulation in Cancer: An Overview in Multiple Myeloma. Int. J. Mol. Sci. 2016, 17, 2003. [CrossRef]

42. Soussi, T.; Lozano, G. P53 Mutation Heterogeneity in Cancer. Biochem. Biophys. Res. Commun. 2005, 331, 834-842. [CrossRef]

43. Joerger, A.C.; Fersht, A.R. The P53 Pathway: Origins, Inactivation in Cancer, and Emerging Therapeutic Approaches. Annu. Rev. Biochem. 2016, 85, 375-404. [CrossRef] [PubMed]

44. Guha, T.; Malkin, D. Inherited TP53 Mutations and the Li-Fraumeni Syndrome. Cold Spring Harb. Perspect. Med. 2017, 7, a026187. [CrossRef]

45. McBride, K.A.; Ballinger, M.L.; Killick, E.; Kirk, J.; Tattersall, M.H.N.; Eeles, R.A.; Thomas, D.M.; Mitchell, G. Li-Fraumeni Syndrome: Cancer Risk Assessment and Clinical Management. Nat. Rev. Clin. Oncol. 2014, 11, 260-271. [CrossRef] [PubMed]

46. Whibley, C.; Pharoah, P.D.P.; Hollstein, M. P53 Polymorphisms: Cancer Implications. Nat. Rev. Cancer 2009, 9, 95-107. [CrossRef]

47. Barnoud, T.; Parris, J.L.D.; Murphy, M.E. Common Genetic Variants in the TP53 Pathway and Their Impact on Cancer. J. Mol. Cell Biol. 2019, 11, 578-585. [CrossRef]

48. Grochola, L.F.; Zeron-Medina, J.; Mériaux, S.; Bond, G.L. Single-Nucleotide Polymorphisms in the P53 Signaling Pathway. Cold Spring Harb. Perspect. Biol. 2010, 2, a001032. [CrossRef]

49. Proestling, K.; Hebar, A.; Pruckner, N.; Marton, E.; Vinatzer, U.; Schreiber, M. The Pro Allele of the P53 Codon 72 Polymorphism Is Associated with Decreased Intratumoral Expression of BAX and P21, and Increased Breast Cancer Risk. PLoS ONE 2012, 7, e47325. [CrossRef]

50. Gunaratna, R.T.; Santos, A.; Luo, L.; Nagi, C.; Lambertz, I.; Spier, M.; Conti, C.J.; Fuchs-Young, R.S. Dynamic Role of the Codon 72 P53 Single-Nucleotide Polymorphism in Mammary Tumorigenesis in a Humanized Mouse Model. Oncogene 2019, 38, 3535-3550. [CrossRef] [PubMed]

51. Storey, A.; Thomas, M.; Kalita, A.; Harwood, C.; Gardiol, D.; Mantovani, F.; Breuer, J.; Leigh, I.M.; Matlashewski, G.; Banks, L. Role of a P53 Polymorphism in the Development of Human Papillomavirus-Associated Cancer. Nature 1998, 393, 229-234. [CrossRef]

52. Rosenthal, A.N.; Ryan, A.; Al-Jehani, R.M.; Storey, A.; Harwood, C.A.; Jacobs, I.J. P53 Codon 72 Polymorphism and Risk of Cervical Cancer in UK. Lancet 1998, 352, 871-872. [CrossRef]

53. Papadakis, E.N.; Dokianakis, D.N.; Spandidos, D.A. P53 Codon 72 Polymorphism as a Risk Factor in the Development of Breast Cancer. Mol. Cell Biol. Res. Commun. 2000, 3, 389-392. [CrossRef]

54. Zhang, Z.; Wang, M.; Wu, D.; Wang, M.; Tong, N.; Tian, Y.; Zhang, Z. P53 Codon 72 Polymorphism Contributes to Breast Cancer Risk: A Meta-Analysis Based on 39 Case-Control Studies. Breast Cancer Res. Treat. 2010, 120, 509-517. [CrossRef]

55. Stracquadanio, G.; Wang, X.; Wallace, M.D.; Grawenda, A.M.; Zhang, P.; Hewitt, J.; Zeron-Medina, J.; Castro-Giner, F.; Tomlinson, I.P.; Goding, C.R.; et al. The Importance of P53 Pathway Genetics in Inherited and Somatic Cancer Genomes. Nat. Rev. Cancer 2016, 16, 251-265. [CrossRef]

56. Green, R.A.; Paluch, E.; Oegema, K. Cytokinesis in Animal Cells. Annu. Rev. Cell Dev. Biol. 2012, 28, 29-58. [CrossRef]

57. Lens, S.M.A.; Medema, R.H. Cytokinesis Defects and Cancer. Nat. Rev. Cancer 2019, 19, 32-45. [CrossRef] [PubMed]

58. Zack, T.I.; Schumacher, S.E.; Carter, S.L.; Cherniack, A.D.; Saksena, G.; Tabak, B.; Lawrence, M.S.; Zhang, C.-Z.; Wala, J.; Mermel, C.H.; et al. Pan-Cancer Patterns of Somatic Copy Number Alteration. Nat. Genet. 2013, 45, 1134-1140. [CrossRef] [PubMed]

59. Ganem, N.J.; Godinho, S.A.; Pellman, D. A Mechanism Linking Extra Centrosomes to Chromosomal Instability. Nature 2009, 460, 278-282. [CrossRef] [PubMed]

60. Sanchez, A.D.; Feldman, J.L. Microtubule-Organizing Centers: From the Centrosome to Non-Centrosomal Sites. Curr. Opin. Cell Biol. 2017, 44, 93-101. [CrossRef] [PubMed]

61. Chan, J.Y. A Clinical Overview of Centrosome Amplification in Human Cancers. Int. J. Biol. Sci. 2011, 7, 1122-1144. [CrossRef]

62. Godinho, S.A.; Picone, R.; Burute, M.; Dagher, R.; Su, Y.; Leung, C.T.; Polyak, K.; Brugge, J.S.; Théry, M.; Pellman, D. Oncogene-like Induction of Cellular Invasion from Centrosome Amplification. Nature 2014, 510, 167-171. [CrossRef]

63. Thompson, S.L.; Compton, D.A. Proliferation of Aneuploid Human Cells Is Limited by a P53-Dependent Mechanism. J. Cell Biol. 2010, 188, 369-381. [CrossRef]

64. Fong, C.S.; Mazo, G.; Das, T.; Goodman, J.; Kim, M.; O’Rourke, B.P.; Izquierdo, D.; Tsou, M.-F.B. 53BP1 and USP28 Mediate P53-Dependent Cell Cycle Arrest in Response to Centrosome Loss and Prolonged Mitosis. eLife 2016, 5, e16270. [CrossRef] [PubMed]

65. Lambrus, B.G.; Daggubati, V.; Uetake, Y.; Scott, P.M.; Clutario, K.M.; Sluder, G.; Holland, A.J. A USP28-53BP1-P53-P21 Signaling Axis Arrests Growth after Centrosome Loss or Prolonged Mitosis. J. Cell Biol. 2016, 214, 143-153. [CrossRef]

66. Meitinger, F.; Anzola, J.V.; Kaulich, M.; Richardson, A.; Stender, J.D.; Benner, C.; Glass, C.K.; Dowdy, S.F.; Desai, A.; Shiau, A.K.; et al. 53BP1 and USP28 Mediate P53 Activation and G1 Arrest after Centrosome Loss or Extended Mitotic Duration. J. Cell Biol. 2016, 214, 155-166. [CrossRef]

67. Panier, S.; Boulton, S.J. Double-Strand Break Repair: 53BP1 Comes into Focus. Nat. Rev. Mol. Cell Biol. 2014, 15, 7-18. [CrossRef] 
68. Lakin, N.D.; Jackson, S.P. Regulation of P53 in Response to DNA Damage. Oncogene 1999, 18, 7644-7655. [CrossRef] [PubMed]

69. Olsson, A.; Manzl, C.; Strasser, A.; Villunger, A. How Important Are Post-Translational Modifications in P53 for Selectivity in Target-Gene Transcription and Tumour Suppression? Cell Death Differ. 2007, 14, 1561-1575. [CrossRef]

70. Zimmermann, M. 53BP1: Pro Choice in DNA Repair. Trends Cell Biol. 2014, 24, 108-117. [CrossRef] [PubMed]

71. Cuella-Martin, R.; Oliveira, C.; Lockstone, H.E.; Snellenberg, S.; Grolmusova, N.; Chapman, J.R. 53BP1 Integrates DNA Repair and P53-Dependent Cell Fate Decisions via Distinct Mechanisms. Mol. Cell 2016, 64, 51-64. [CrossRef]

72. Fava, L.L.; Schuler, F.; Sladky, V.; Haschka, M.D.; Soratroi, C.; Eiterer, L.; Demetz, E.; Weiss, G.; Geley, S.; Nigg, E.A.; et al. The PIDDosome Activates P53 in Response to Supernumerary Centrosomes. Genes Dev. 2017, 31, 34-45. [CrossRef]

73. Tinel, A.; Tschopp, J. The PIDDosome, a Protein Complex Implicated in Activation of Caspase-2 in Response to Genotoxic Stress. Science 2004, 304, 843-846. [CrossRef] [PubMed]

74. Resnick-Silverman, L.; Clair, S.S.; Maurer, M.; Zhao, K.; Manfredi, J.J. Identification of a Novel Class of Genomic DNA-Binding Sites Suggests a Mechanism for Selectivity in Target Gene Activation by the Tumor Suppressor Protein P53. Genes Dev. 1998, 12, 2102-2107. [CrossRef] [PubMed]

75. Al Bitar, S.; Gali-Muhtasib, H. The Role of the Cyclin Dependent Kinase Inhibitor P21cip1/Waf1 in Targeting Cancer: Molecular Mechanisms and Novel Therapeutics. Cancers 2019, 11, 1475. [CrossRef] [PubMed]

76. Giacinti, C.; Giordano, A. RB and Cell Cycle Progression. Oncogene 2006, 25, 5220-5227. [CrossRef]

77. Andrysik, Z.; Galbraith, M.D.; Guarnieri, A.L.; Zaccara, S.; Sullivan, K.D.; Pandey, A.; MacBeth, M.; Inga, A.; Espinosa, J.M. Identification of a Core TP53 Transcriptional Program with Highly Distributed Tumor Suppressive Activity. Genome Res. 2017, 27, 1645-1657. [CrossRef]

78. Taylor, W.R.; Stark, G.R. Regulation of the G2/M Transition by P53. Oncogene 2001, 20, 1803-1815. [CrossRef] [PubMed]

79. Zhan, Q. Gadd45a, a P53- and BRCA1-Regulated Stress Protein, in Cellular Response to DNA Damage. Mutat. Res./Fundam. Mol. Mech. Mutagenesis 2005, 569, 133-143. [CrossRef]

80. Eckerdt, F.; Yuan, J.; Strebhardt, K. Polo-like Kinases and Oncogenesis. Oncogene 2005, 24, 267-276. [CrossRef]

81. Fischer, M.; Steiner, L.; Engeland, K. The Transcription Factor P53: Not a Repressor, Solely an Activator. Cell Cycle 2014, 13, 3037-3058. [CrossRef]

82. Fischer, M.; Quaas, M.; Steiner, L.; Engeland, K. The P53-P21-DREAM-CDE/CHR Pathway Regulates G2/M Cell Cycle Genes. Nucleic Acids Res. 2016, 44, 164-174. [CrossRef]

83. Fischer, M.; Grossmann, P.; Padi, M.; DeCaprio, J.A. Integration of TP53, DREAM, MMB-FOXM1 and RB-E2F Target Gene Analyses Identifies Cell Cycle Gene Regulatory Networks. Nucleic Acids Res. 2016, 44, 6070-6086. [CrossRef] [PubMed]

84. Sadasivam, S.; DeCaprio, J.A. The DREAM Complex: Master Coordinator of Cell Cycle-Dependent Gene Expression. Nat. Rev. Cancer 2013, 13, 585-595. [CrossRef] [PubMed]

85. Engeland, K. Cell Cycle Arrest through Indirect Transcriptional Repression by P53: I Have a DREAM. Cell Death Differ. 2018, 25, 114-132. [CrossRef]

86. Graña, X.; Garriga, J.; Mayol, X. Role of the Retinoblastoma Protein Family, PRB, P107 and P130 in the Negative Control of Cell Growth. Oncogene 1998, 17, 3365-3383. [CrossRef] [PubMed]

87. Stengel, K.R.; Thangavel, C.; Solomon, D.A.; Angus, S.P.; Zheng, Y.; Knudsen, E.S. Retinoblastoma/P107/P130 Pocket Proteins: Protein dynamics and interactions with target gene promoters. J. Biol. Chem. 2009, 284, 19265-19271. [CrossRef] [PubMed]

88. Quaas, M.; Müller, G.A.; Engeland, K. P53 Can Repress Transcription of Cell Cycle Genes through a P21WAF1/CIP1-Dependent Switch from MMB to DREAM Protein Complex Binding at CHR Promoter Elements. Cell Cycle 2012, 11, 4661-4672. [CrossRef]

89. Kumari, R.; Jat, P. Mechanisms of Cellular Senescence: Cell Cycle Arrest and Senescence Associated Secretory Phenotype. Front. Cell Dev. Biol. 2021, 9, 485. [CrossRef]

90. Sage, J.; Miller, A.L.; Pérez-Mancera, P.A.; Wysocki, J.M.; Jacks, T. Acute Mutation of Retinoblastoma Gene Function Is Sufficient for Cell Cycle Re-Entry. Nature 2003, 424, 223-228. [CrossRef]

91. Beausejour, C.M. Reversal of Human Cellular Senescence: Roles of the P53 and P16 Pathways. EMBO J. 2003, $22,4212-4222$. [CrossRef]

92. Gire, V.; Wynford-Thomas, D. Reinitiation of DNA Synthesis and Cell Division in Senescent Human Fibroblasts by Microinjection of Anti-P53 Antibodies. Mol. Cell. Biol. 1998, 18, 1611-1621. [CrossRef]

93. Lee, S.; Schmitt, C.A. The Dynamic Nature of Senescence in Cancer. Nat. Cell Biol. 2019, 21, 94-101. [CrossRef]

94. Litovchick, L.; Florens, L.A.; Swanson, S.K.; Washburn, M.P.; DeCaprio, J.A. DYRK1A Protein Kinase Promotes Quiescence and Senescence through DREAM Complex Assembly. Genes Dev. 2011, 25, 801-813. [CrossRef]

95. Hauser, S.; Ulrich, T.; Wurster, S.; Schmitt, K.; Reichert, N.; Gaubatz, S. Loss of LIN9, a Member of the DREAM Complex, Cooperates with SV40 Large T Antigen to Induce Genomic Instability and Anchorage-Independent Growth. Oncogene 2012, 31, 1859-1868. [CrossRef]

96. Reichert, N.; Wurster, S.; Ulrich, T.; Schmitt, K.; Hauser, S.; Probst, L.; Götz, R.; Ceteci, F.; Moll, R.; Rapp, U.; et al. Lin9, a Subunit of the Mammalian DREAM Complex, Is Essential for Embryonic Development, for Survival of Adult Mice, and for Tumor Suppression. Mol. Cell. Biol. 2010, 30, 2896-2908. [CrossRef] [PubMed]

97. Lin, Y.; Ma, W.; Benchimol, S. Pidd, a New Death-Domain-Containing Protein, Is Induced by P53 and Promotes Apoptosis. Nat. Genet 2000, 26, 122-127. [CrossRef] [PubMed] 
98. Sladky, V.C.; Knapp, K.; Soratroi, C.; Heppke, J.; Eichin, F.; Rocamora-Reverte, L.; Szabo, T.G.; Bongiovanni, L.; Westendorp, B.; Moreno, E.; et al. E2F-Family Members Engage the PIDDosome to Limit Hepatocyte Ploidy in Liver Development and Regeneration. Dev. Cell 2020, 52, 335-349.e7. [CrossRef]

99. Fischer, M. Census and Evaluation of P53 Target Genes. Oncogene 2017, 36, 3943-3956. [CrossRef] [PubMed]

100. Nakano, K.; Vousden, K.H. PUMA, a Novel Proapoptotic Gene, Is Induced by P53. Mol. Cell 2001, 7, 683-694. [CrossRef]

101. Villunger, A.; Michalak, E.M.; Coultas, L.; Müllauer, F.; Böck, G.; Ausserlechner, M.J.; Adams, J.M.; Strasser, A. P53- and Drug-Induced Apoptotic Responses Mediated by BH3-Only Proteins Puma and Noxa. Science 2003, 302, 1036-1038. [CrossRef] [PubMed]

102. Naik, E.; Michalak, E.M.; Villunger, A.; Adams, J.M.; Strasser, A. Ultraviolet Radiation Triggers Apoptosis of Fibroblasts and Skin Keratinocytes Mainly via the BH3-Only Protein Noxa. J. Cell Biol. 2007, 176, 415-424. [CrossRef] [PubMed]

103. Oda, E.; Ohki, R.; Murasawa, H.; Nemoto, J.; Shibue, T.; Yamashita, T.; Tokino, T.; Taniguchi, T.; Tanaka, N. Noxa, a BH3-Only Member of the Bcl-2 Family and Candidate Mediator of P53-Induced Apoptosis. Science 2000, 288, 1053-1058. [CrossRef] [PubMed]

104. Czabotar, P.E.; Lessene, G.; Strasser, A.; Adams, J.M. Control of Apoptosis by the BCL-2 Protein Family: Implications for Physiology and Therapy. Nat. Rev. Mol. Cell Biol. 2014, 15, 49-63. [CrossRef]

105. Letai, A.; Bassik, M.C.; Walensky, L.D.; Sorcinelli, M.D.; Weiler, S.; Korsmeyer, S.J. Distinct BH3 Domains Either Sensitize or Activate Mitochondrial Apoptosis, Serving as Prototype Cancer Therapeutics. Cancer Cell 2002, 2, 183-192. [CrossRef]

106. Sax, J.K.; Fei, P.; Murphy, M.E.; Bernhard, E.; Korsmeyer, S.J.; El-Deiry, W.S. BID Regulation by P53 Contributes to Chemosensitivity. Nat. Cell Biol. 2002, 4, 842-849. [CrossRef]

107. Selvakumaran, M.; Lin, H.K.; Miyashita, T.; Wang, H.G.; Krajewski, S.; Reed, J.C.; Hoffman, B.; Liebermann, D. Immediate Early Up-Regulation of Bax Expression by P53 but Not TGF Beta 1: A Paradigm for Distinct Apoptotic Pathways. Oncogene 1994, 9 , 1791-1798.

108. Toshiyuki, M.; Reed, J.C. Tumor Suppressor P53 Is a Direct Transcriptional Activator of the Human Bax Gene. Cell 1995, 80, 293-299. [CrossRef]

109. Marchenko, N.D.; Zaika, A.; Moll, U.M. Death Signal-Induced Localization of P53 Protein to Mitochondria: A potential role in apoptotic signaling. J. Biol. Chem. 2000, 275, 16202-16212. [CrossRef]

110. Mihara, M.; Erster, S.; Zaika, A.; Petrenko, O.; Chittenden, T.; Pancoska, P.; Moll, U.M. P53 Has a Direct Apoptogenic Role at the Mitochondria. Mol. Cell 2003, 11, 577-590. [CrossRef]

111. Chipuk, J.E.; Kuwana, T.; Bouchier-Hayes, L.; Droin, N.M.; Newmeyer, D.D.; Schuler, M.; Green, D.R. Direct Activation of Bax by P53 Mediates Mitochondrial Membrane Permeabilization and Apoptosis. Science 2004, 303, 1010-1014. [CrossRef]

112. Leu, J.I.-J.; Dumont, P.; Hafey, M.; Murphy, M.E.; George, D.L. Mitochondrial P53 Activates Bak and Causes Disruption of a Bak-Mcl1 Complex. Nat. Cell Biol. 2004, 6, 443-450. [CrossRef] [PubMed]

113. Follis, A.V.; Chipuk, J.E.; Fisher, J.C.; Yun, M.-K.; Grace, C.R.; Nourse, A.; Baran, K.; Ou, L.; Min, L.; White, S.W.; et al. PUMA Binding Induces Partial Unfolding within BCL-XL to Disrupt P53 Binding and Promote Apoptosis. Nat. Chem. Biol. 2013, 9, 163-168. [CrossRef]

114. Wei, H.; Qu, L.; Dai, S.; Li, Y.; Wang, H.; Feng, Y.; Chen, X.; Jiang, L.; Guo, M.; Li, J.; et al. Structural Insight into the Molecular Mechanism of P53-Mediated Mitochondrial Apoptosis. Nat. Commun. 2021, 12, 2280. [CrossRef]

115. Mai, W.X.; Gosa, L.; Daniels, V.W.; Ta, L.; Tsang, J.E.; Higgins, B.; Gilmore, W.B.; Bayley, N.A.; Harati, M.D.; Lee, J.T.; et al. Cytoplasmic P53 Couples Oncogene-Driven Glucose Metabolism to Apoptosis and Is a Therapeutic Target in Glioblastoma. Nat. Med. 2017, 23, 1342-1351. [CrossRef] [PubMed]

116. Kannan, K.; Kaminski, N.; Rechavi, G.; Jakob-Hirsch, J.; Amariglio, N.; Givol, D. DNA Microarray Analysis of Genes Involved in P53 Mediated Apoptosis: Activation of Apaf-1. Oncogene 2001, 20, 3449-3455. [CrossRef] [PubMed]

117. Robles, A.I.; Bemmels, N.A.; Foraker, A.B.; Harris, C.C. APAF-1 Is a Transcriptional Target of P53 in DNA Damage-Induced Apoptosis. Cancer Res. 2001, 61, 6660-6664.

118. Potting, C.; Tatsuta, T.; König, T.; Haag, M.; Wai, T.; Aaltonen, M.J.; Langer, T. TRIAP1/PRELI Complexes Prevent Apoptosis by Mediating Intramitochondrial Transport of Phosphatidic Acid. Cell Metab. 2013, 18, 287-295. [CrossRef] [PubMed]

119. Park, W.-R.; Nakamura, Y. P53CSV, a Novel P53-Inducible Gene Involved in the P53-Dependent Cell-Survival Pathway. Cancer Res. 2005, 65, 1197-1206. [CrossRef]

120. Carneiro, B.A.; El-Deiry, W.S. Targeting Apoptosis in Cancer Therapy. Nat. Rev. Clin. Oncol. 2020, 17, 395-417. [CrossRef]

121. Müller, M.; Wilder, S.; Bannasch, D.; Israeli, D.; Lehlbach, K.; Li-Weber, M.; Friedman, S.L.; Galle, P.R.; Stremmel, W.; Oren, M.; et al. P53 Activates the CD95 (APO-1/Fas) Gene in Response to DNA Damage by Anticancer Drugs. J. Exp. Med. 1998, 188, 2033-2045. [CrossRef]

122. Liu, X.; Yue, P.; Khuri, F.R.; Sun, S.-Y. P53 Upregulates Death Receptor 4 Expression through an Intronic P53 Binding Site. Cancer Res. 2004, 64, 5078-5083. [CrossRef]

123. Wu, G.S.; Burns, T.F.; McDonald, E.R.; Jiang, W.; Meng, R.; Krantz, I.D.; Kao, G.; Gan, D.-D.; Zhou, J.-Y.; Muschel, R.; et al. KILLER/DR5 Is a DNA Damage-Inducible P53-Regulated Death Receptor Gene. Nat. Genet. 1997, 17, 141-143. [CrossRef] [PubMed] 
124. Sprick, M.R.; Weigand, M.A.; Rieser, E.; Rauch, C.T.; Juo, P.; Blenis, J.; Krammer, P.H.; Walczak, H. FADD/MORT1 and Caspase-8 Are Recruited to TRAIL Receptors 1 and 2 and Are Essential for Apoptosis Mediated by TRAIL Receptor 2. Immunity 2000, 12, 599-609. [CrossRef]

125. Kischkel, F.C.; Lawrence, D.A.; Chuntharapai, A.; Schow, P.; Kim, K.J.; Ashkenazi, A. Apo2L/TRAIL-Dependent Recruitment of Endogenous FADD and Caspase-8 to Death Receptors 4 and 5. Immunity 2000, 12, 611-620. [CrossRef]

126. Bodmer, J.-L.; Holler, N.; Reynard, S.; Vinciguerra, P.; Schneider, P.; Juo, P.; Blenis, J.; Tschopp, J. TRAIL Receptor-2 Signals Apoptosis through FADD and Caspase-8. Nat. Cell Biol. 2000, 2, 241-243. [CrossRef] [PubMed]

127. Li, H.; Zhu, H.; Xu, C.; Yuan, J. Cleavage of BID by Caspase 8 Mediates the Mitochondrial Damage in the Fas Pathway of Apoptosis. Cell 1998, 94, 491-501. [CrossRef]

128. Luo, X.; Budihardjo, I.; Zou, H.; Slaughter, C.; Wang, X. Bid, a Bcl2 Interacting Protein, Mediates Cytochrome c Release from Mitochondria in Response to Activation of Cell Surface Death Receptors. Cell 1998, 94, 481-490. [CrossRef]

129. Liu, X.; Yue, P.; Khuri, F.R.; Sun, S.-Y. Decoy Receptor 2 (DcR2) Is a P53 Target Gene and Regulates Chemosensitivity. Cancer Res. 2005, 65, 9169-9175. [CrossRef]

130. Sheikh, M.S.; Huang, Y.; Fernandez-Salas, E.A.; El-Deiry, W.S.; Friess, H.; Amundson, S.; Yin, J.; Meltzer, S.J.; Holbrook, N.J.; Fornace, A.J. The Antiapoptotic Decoy Receptor TRID/TRAIL-R3 Is a P53-Regulated DNA Damage-Inducible Gene That Is Overexpressed in Primary Tumors of the Gastrointestinal Tract. Oncogene 1999, 18, 4153-4159. [CrossRef]

131. Fais, S.; Overholtzer, M. Cell-in-Cell Phenomena in Cancer. Nat. Rev. Cancer 2018, 18, 758-766. [CrossRef]

132. Overholtzer, M.; Brugge, J.S. The Cell Biology of Cell-in-Cell Structures. Nat. Rev. Mol. Cell Biol. 2008, 9, 796-809. [CrossRef]

133. Overholtzer, M.; Mailleux, A.A.; Mouneimne, G.; Normand, G.; Schnitt, S.J.; King, R.W.; Cibas, E.S.; Brugge, J.S. A Nonapoptotic Cell Death Process, Entosis, That Occurs by Cell-in-Cell Invasion. Cell 2007, 131, 966-979. [CrossRef]

134. Krajcovic, M.; Johnson, N.B.; Sun, Q.; Normand, G.; Hoover, N.; Yao, E.; Richardson, A.L.; King, R.W.; Cibas, E.S.; Schnitt, S.J.; et al. A Non-Genetic Route to Aneuploidy in Human Cancers. Nat. Cell Biol. 2011, 13, 324-330. [CrossRef]

135. Mackay, H.L.; Moore, D.; Hall, C.; Birkbak, N.J.; Jamal-Hanjani, M.; Karim, S.A.; Phatak, V.M.; Piñon, L.; Morton, J.P.; Swanton, C.; et al. Genomic Instability in Mutant P53 Cancer Cells upon Entotic Engulfment. Nat. Commun. 2018, 9, 3070. [CrossRef]

136. Durgan, J.; Tseng, Y.-Y.; Hamann, J.C.; Domart, M.-C.; Collinson, L.; Hall, A.; Overholtzer, M.; Florey, O. Mitosis Can Drive Cell Cannibalism through Entosis. eLife 2017, 6, e27134. [CrossRef]

137. Liang, J.; Niu, Z.; Zhang, B.; Yu, X.; Zheng, Y.; Wang, C.; Ren, H.; Wang, M.; Ruan, B.; Qin, H.; et al. P53-Dependent Elimination of Aneuploid Mitotic Offspring by Entosis. Cell Death Differ. 2021, 28, 799-813. [CrossRef]

138. Dixon, S.J.; Lemberg, K.M.; Lamprecht, M.R.; Skouta, R.; Zaitsev, E.M.; Gleason, C.E.; Patel, D.N.; Bauer, A.J.; Cantley, A.M.; Yang, W.S.; et al. Ferroptosis: An Iron-Dependent Form of Nonapoptotic Cell Death. Cell 2012, 149, 1060-1072. [CrossRef] [PubMed]

139. Kang, R.; Kroemer, G.; Tang, D. The Tumor Suppressor Protein P53 and the Ferroptosis Network. Free Radic. Biol. Med. 2019, 133, 162-168. [CrossRef] [PubMed]

140. Yang, W.S.; SriRamaratnam, R.; Welsch, M.E.; Shimada, K.; Skouta, R.; Viswanathan, V.S.; Cheah, J.H.; Clemons, P.A.; Shamji, A.F.; Clish, C.B.; et al. Regulation of Ferroptotic Cancer Cell Death by GPX4. Cell 2014, 156, 317-331. [CrossRef] [PubMed]

141. Jiang, L.; Kon, N.; Li, T.; Wang, S.-J.; Su, T.; Hibshoosh, H.; Baer, R.; Gu, W. Ferroptosis as a P53-Mediated Activity during Tumour Suppression. Nature 2015, 520, 57-62. [CrossRef] [PubMed]

142. Li, T.; Liu, X.; Jiang, L.; Manfredi, J.; Zha, S.; Gu, W. Loss of P53-Mediated Cell-Cycle Arrest, Senescence and Apoptosis Promotes Genomic Instability and Premature Aging. Oncotarget 2016, 7, 11838-11849. [CrossRef]

143. Ou, Y.; Wang, S.-J.; Li, D.; Chu, B.; Gu, W. Activation of SAT1 Engages Polyamine Metabolism with P53-Mediated Ferroptotic Responses. PNAS 2016, 113, E6806-E6812. [CrossRef]

144. Chu, B.; Kon, N.; Chen, D.; Li, T.; Liu, T.; Jiang, L.; Song, S.; Tavana, O.; Gu, W. ALOX12 Is Required for P53-Mediated Tumour Suppression through a Distinct Ferroptosis Pathway. Nat. Cell Biol. 2019, 21, 579-591. [CrossRef]

145. Zhang, Y.; Qian, Y.; Zhang, J.; Yan, W.; Jung, Y.-S.; Chen, M.; Huang, E.; Lloyd, K.; Duan, Y.; Wang, J.; et al. Ferredoxin Reductase Is Critical for P53-Dependent Tumor Suppression via Iron Regulatory Protein 2. Genes Dev. 2017, 31, 1243-1256. [CrossRef]

146. Gao, M.; Monian, P.; Quadri, N.; Ramasamy, R.; Jiang, X. Glutaminolysis and Transferrin Regulate Ferroptosis. Mol. Cell 2015, 59, 298-308. [CrossRef]

147. Wang, S.-J.; Li, D.; Ou, Y.; Jiang, L.; Chen, Y.; Zhao, Y.; Gu, W. Acetylation Is Crucial for P53-Mediated Ferroptosis and Tumor Suppression. Cell Rep. 2016, 17, 366-373. [CrossRef]

148. Xie, Y.; Zhu, S.; Song, X.; Sun, X.; Fan, Y.; Liu, J.; Zhong, M.; Yuan, H.; Zhang, L.; Billiar, T.R.; et al. The Tumor Suppressor P53 Limits Ferroptosis by Blocking DPP4 Activity. Cell Rep. 2017, 20, 1692-1704. [CrossRef] [PubMed]

149. Tarangelo, A.; Magtanong, L.; Bieging-Rolett, K.T.; Li, Y.; Ye, J.; Attardi, L.D.; Dixon, S.J. P53 Suppresses Metabolic Stress-Induced Ferroptosis in Cancer Cells. Cell Rep. 2018, 22, 569-575. [CrossRef] [PubMed]

150. Vitale, I.; Galluzzi, L.; Castedo, M.; Kroemer, G. Mitotic Catastrophe: A Mechanism for Avoiding Genomic Instability. Nat. Rev. Mol. Cell Biol. 2011, 12, 385-392. [CrossRef] [PubMed]

151. Vitale, I.; Manic, G.; Castedo, M.; Kroemer, G. Caspase 2 in Mitotic Catastrophe: The Terminator of Aneuploid and Tetraploid Cells. Mol. Cell. Oncol. 2017, 4, e1299274. [CrossRef] [PubMed]

152. Brown-Suedel, A.N.; Bouchier-Hayes, L. Caspase-2 Substrates: To Apoptosis, Cell Cycle Control, and Beyond. Front. Cell Dev. Biol. 2020, 8, 1662. [CrossRef] [PubMed] 
153. Manzl, C.; Krumschnabel, G.; Bock, F.; Sohm, B.; Labi, V.; Baumgartner, F.; Logette, E.; Tschopp, J.; Villunger, A. Caspase-2 Activation in the Absence of PIDDosome Formation. J. Cell Biol. 2009, 185, 291-303. [CrossRef]

154. Manzl, C.; Peintner, L.; Krumschnabel, G.; Bock, F.; Labi, V.; Drach, M.; Newbold, A.; Johnstone, R.; Villunger, A. PIDDosomeIndependent Tumor Suppression by Caspase-2. Cell Death Differ. 2012, 19, 1722-1732. [CrossRef]

155. Oliver, T.G.; Meylan, E.; Chang, G.P.; Xue, W.; Burke, J.R.; Humpton, T.J.; Hubbard, D.; Bhutkar, A.; Jacks, T. Caspase-2-Mediated Cleavage of Mdm2 Creates a P53-Induced Positive Feedback Loop. Mol. Cell 2011, 43, 57-71. [CrossRef]

156. Tsabar, M.; Mock, C.S.; Venkatachalam, V.; Reyes, J.; Karhohs, K.W.; Oliver, T.G.; Regev, A.; Jambhekar, A.; Lahav, G. A Switch in P53 Dynamics Marks Cells That Escape from DSB-Induced Cell Cycle Arrest. Cell Rep. 2020, 32, 107995. [CrossRef]

157. Ho, L.; Taylor, R.; Dorstyn, L.; Cakouros, D.; Bouillet, P.; Kumar, S. A Tumor Suppressor Function for Caspase-2. Proc. Natl. Acad. Sci. USA 2009, 106, 5336-5341. [CrossRef] [PubMed]

158. Dawar, S.; Lim, Y.; Puccini, J.; White, M.; Thomas, P.; Bouchier-Hayes, L.; Green, D.R.; Dorstyn, L.; Kumar, S. Caspase-2-Mediated Cell Death Is Required for Deleting Aneuploid Cells. Oncogene 2017, 36, 2704-2714. [CrossRef]

159. Dorstyn, L.; Puccini, J.; Wilson, C.H.; Shalini, S.; Nicola, M.; Moore, S.; Kumar, S. Caspase-2 Deficiency Promotes Aberrant DNA-Damage Response and Genetic Instability. Cell Death Differ. 2012, 19, 1288-1298. [CrossRef] [PubMed]

160. Ranjan, A.; Iwakuma, T. Non-Canonical Cell Death Induced by P53. Int. J. Mol. Sci. 2016, 17, 2068. [CrossRef]

161. Kroemer, G.; Levine, B. Autophagic Cell Death: The Story of a Misnomer. Nat. Rev. Mol. Cell Biol. 2008, 9, 1004-1010. [CrossRef]

162. Crighton, D.; Wilkinson, S.; O’Prey, J.; Syed, N.; Smith, P.; Harrison, P.R.; Gasco, M.; Garrone, O.; Crook, T.; Ryan, K.M. DRAM, a P53-Induced Modulator of Autophagy, Is Critical for Apoptosis. Cell 2006, 126, 121-134. [CrossRef] [PubMed]

163. Crighton, D.; Wilkinson, S.; Ryan, K.M. DRAM Links Autophagy to P53 and Programmed Cell Death. Autophagy 2007, 3, 72-74. [CrossRef] [PubMed]

164. Cui, L.; Song, Z.; Liang, B.; Jia, L.; Ma, S.; Liu, X. Radiation Induces Autophagic Cell Death via the P53/DRAM Signaling Pathway in Breast Cancer Cells. Oncol. Rep. 2016, 35, 3639-3647. [CrossRef] [PubMed]

165. Park, K.-J.; Lee, S.-H.; Lee, C.-H.; Jang, J.-Y.; Chung, J.; Kwon, M.-H.; Kim, Y.-S. Upregulation of Beclin-1 Expression and Phosphorylation of Bcl-2 and P53 Are Involved in the JNK-Mediated Autophagic Cell Death. Biochem. Biophys. Res. Commun. 2009, 382, 726-729. [CrossRef]

166. Cheng, Y.; Qiu, F.; Tashiro, S.; Onodera, S.; Ikejima, T. ERK and JNK Mediate TNF $\alpha$-Induced P53 Activation in Apoptotic and Autophagic L929 Cell Death. Biochem. Biophys. Res. Commun. 2008, 376, 483-488. [CrossRef]

167. Kim, S.M.; Ha, S.E.; Lee, H.J.; Rampogu, S.; Vetrivel, P.; Kim, H.H.; Venkatarame Gowda Saralamma, V.; Lee, K.W.; Kim, G.S. Sinensetin Induces Autophagic Cell Death through P53-Related AMPK/MTOR Signaling in Hepatocellular Carcinoma HepG2 Cells. Nutrients 2020, 12, 2462. [CrossRef]

168. Liu, J.; Xia, H.; Kim, M.; Xu, L.; Li, Y.; Zhang, L.; Cai, Y.; Norberg, H.V.; Zhang, T.; Furuya, T.; et al. Beclin1 Controls the Levels of P53 by Regulating the Deubiquitination Activity of USP10 and USP13. Cell 2011, 147, 223-234. [CrossRef]

169. Sperandio, S.; de Belle, I.; Bredesen, D.E. An Alternative, Nonapoptotic Form of Programmed Cell Death. PNAS 2000, 97, 14376-14381. [CrossRef] [PubMed]

170. Li, B.; Zhao, J.; Wang, C.-Z.; Searle, J.; He, T.-C.; Yuan, C.-S.; Du, W. Ginsenoside Rh2 Induces Apoptosis and Paraptosis-like Cell Death in Colorectal Cancer Cells through Activation of P53. Cancer Lett. 2011, 301, 185-192. [CrossRef]

171. Pehar, M.; O’Riordan, K.J.; Burns-Cusato, M.; Andrzejewski, M.E.; del Alcazar, C.G.; Burger, C.; Scrable, H.; Puglielli, L. Altered Longevity-Assurance Activity of P53:P44 in the Mouse Causes Memory Loss, Neurodegeneration and Premature Death. Aging Cell 2010, 9, 174-190. [CrossRef] [PubMed]

172. Lee, D.M.; Kim, I.Y.; Seo, M.J.; Kwon, M.R.; Choi, K.S. Nutlin-3 Enhances the Bortezomib Sensitivity of P53-Defective Cancer Cells by Inducing Paraptosis. Exp. Mol. Med. 2017, 49, e365. [CrossRef] [PubMed]

173. Bensaad, K.; Vousden, K.H. P53: New Roles in Metabolism. Trends Cell Biol. 2007, 17, 286-291. [CrossRef]

174. Stewart-Ornstein, J.; Iwamoto, Y.; Miller, M.A.; Prytyskach, M.A.; Ferretti, S.; Holzer, P.; Kallen, J.; Furet, P.; Jambhekar, A.; Forrester, W.C.; et al. P53 Dynamics Vary between Tissues and Are Linked with Radiation Sensitivity. Nat. Commun. 2021, 12, 898. [CrossRef]

175. Tovar, C.; Rosinski, J.; Filipovic, Z.; Higgins, B.; Kolinsky, K.; Hilton, H.; Zhao, X.; Vu, B.T.; Qing, W.; Packman, K.; et al. SmallMolecule MDM2 Antagonists Reveal Aberrant P53 Signaling in Cancer: Implications for Therapy. PNAS 2006, 103, $1888-1893$. [CrossRef]

176. DeHart, C.J.; Chahal, J.S.; Flint, S.J.; Perlman, D.H. Extensive Post-Translational Modification of Active and Inactivated Forms of Endogenous P53. Mol. Cell. Proteom. 2014, 13, 1-17. [CrossRef]

177. Liu, Y.; Tavana, O.; Gu, W. P53 Modifications: Exquisite Decorations of the Powerful Guardian. J. Mol. Cell Biol. 2019, 11, 564-577. [CrossRef] [PubMed]

178. Wen, J.; Wang, D. Deciphering the PTM Codes of the Tumor Suppressor P53. J. Mol. Cell Biol. 2021. [CrossRef]

179. Liebl, M.C.; Hofmann, T.G. Cell Fate Regulation upon DNA Damage: P53 Serine 46 Kinases Pave the Cell Death Road. BioEssays 2019, 41, 1900127. [CrossRef] [PubMed]

180. Smeenk, L.; van Heeringen, S.J.; Koeppel, M.; Gilbert, B.; Janssen-Megens, E.; Stunnenberg, H.G.; Lohrum, M. Role of P53 Serine 46 in P53 Target Gene Regulation. PLoS ONE 2011, 6, e17574. [CrossRef] 
181. Ichwan, S.J.A.; Yamada, S.; Sumrejkanchanakij, P.; Ibrahim-Auerkari, E.; Eto, K.; Ikeda, M.-A. Defect in Serine 46 Phosphorylation of P53 Contributes to Acquisition of P53 Resistance in Oral Squamous Cell Carcinoma Cells. Oncogene 2006, 25, 1216-1224. [CrossRef] [PubMed]

182. Lahav, G.; Rosenfeld, N.; Sigal, A.; Geva-Zatorsky, N.; Levine, A.J.; Elowitz, M.B.; Alon, U. Dynamics of the P53-Mdm2 Feedback Loop in Individual Cells. Nat Genet 2004, 36, 147-150. [CrossRef] [PubMed]

183. Purvis, J.E.; Karhohs, K.W.; Mock, C.; Batchelor, E.; Loewer, A.; Lahav, G. P53 Dynamics Control Cell Fate. Science 2012, 336, 1440-1444. [CrossRef]

184. Kracikova, M.; Akiri, G.; George, A.; Sachidanandam, R.; Aaronson, S.A. A Threshold Mechanism Mediates P53 Cell Fate Decision between Growth Arrest and Apoptosis. Cell Death Differ. 2013, 20, 576-588. [CrossRef]

185. Paek, A.L.; Liu, J.C.; Loewer, A.; Forrester, W.C.; Lahav, G. Cell-to-Cell Variation in P53 Dynamics Leads to Fractional Killing. Cell 2016, 165, 631-642. [CrossRef]

186. Hafner, A.; Stewart-Ornstein, J.; Purvis, J.E.; Forrester, W.C.; Bulyk, M.L.; Lahav, G. P53 Pulses Lead to Distinct Patterns of Gene Expression Albeit Similar DNA-Binding Dynamics. Nat. Struct. Mol. Biol. 2017, 24, 840-847. [CrossRef]

187. Rizzotto, D.; Zaccara, S.; Rossi, A.; Galbraith, M.D.; Andrysik, Z.; Pandey, A.; Sullivan, K.D.; Quattrone, A.; Espinosa, J.M.; Dassi, E.; et al. Nutlin-Induced Apoptosis Is Specified by a Translation Program Regulated by PCBP2 and DHX30. Cell Rep. 2020, 30, 4355-4369.e6. [CrossRef] [PubMed]

188. Freeman, J.A.; Espinosa, J.M. The Impact of Post-Transcriptional Regulation in the P53 Network. Brief. Funct. Genom. 2013, 12, 46-57. [CrossRef] [PubMed]

189. Zaccara, S.; Tebaldi, T.; Pederiva, C.; Ciribilli, Y.; Bisio, A.; Inga, A. P53-Directed Translational Control Can Shape and Expand the Universe of P53 Target Genes. Cell Death Differ. 2014, 21, 1522-1534. [CrossRef] 